\title{
Cheese whey management by catalytic steam reforming and aqueous phase reforming
}

\author{
J. Remón, L. García*, J. Arauzo
}

Thermochemical Processes Group (GPT), Aragón Institute for Engineering Research (I3A), Universidad de Zaragoza. Mariano Esquillor s/n, E-50018 Zaragoza, Spain. *Corresponding author. Tel: +34 976 762194; Fax.: +34 976 761879; e-mail: luciag@unizar.es

\begin{abstract}
Cheese whey is a yellowish liquid by-product of the cheese making process. Owing to its high BOD and COD values, this feedstock should not be directly discharged into the environment without appropriate treatment. The management of this wastewater has become an important issue, and new treatments must be sought. This work addresses the valorisation of cheese whey by steam reforming and aqueous phase reforming. The catalytic steam reforming of cheese whey turned out to be a promising valorisation route for $\mathrm{H}_{2}$ production from this effluent. This process enabled the organic compounds present in the cheese whey to be transformed into a rich $\mathrm{H}_{2}$ gas $(35 \%$ of the $\mathrm{C}$ of the feed was transformed into a gas with 70 vol. $\%$ of $\mathrm{H}_{2}$ ). This significantly reduced the amount of carbon present in the original feedstock, producing an almost carbon-free liquid stream. The aqueous phase reforming of cheese whey allowed $35 \%$ of the carbon present in the whey to be transformed into gases and $45 \%$ into valuable liquids. The gas was principally made up of $\mathrm{H}_{2}$ and $\mathrm{CO}_{2}$, while a mixture of added-value liquids such as aldehydes, carboxylic acids, alcohols and ketones constituted the liquid phase. However, both valorisation routes produced a substantial amount of solid. The formation of this solid was promoted by the presence of salts in the original feedstock and caused operational problems for both valorisation processes. In addition, it hampered gas production in the case of steam reforming and reduced gas and liquid formation when using aqueous phase reforming as the valorisation route. The filtration
\end{abstract}


of cheese whey slightly decreased the solid formation in both processes due to the reduction of proteins and fats, both of which partly contribute to such formation. Less solid was formed in the experiments conducted with lactose than in those conducted with whole and with filtered cheese whey.

Keywords: cheese whey, steam reforming, aqueous phase reforming, renewable hydrogen and value-added liquids. 


\section{Introduction}

Cheese whey is a yellowish liquid resulting from the coprecipitation and removal of milk casein in cheese-making processes. On average, $9 \mathrm{~kg}$ of cheese whey is produced during the production of $1 \mathrm{~kg}$ of cheese, which corresponds to a worldwide production of 5 million tons a year. The typical composition of this effluent is 4.5-6 wt.\% lactose, 0.6-1.1 wt.\% proteins, 0.8-1 wt.\% minerals, 0.05-0.9 wt.\% lactic acid, 0.06-0.5 wt.\% fats and 93-94 wt.\% water [1-4]. It has BOD and COD values ranging from 27-60 $\mathrm{kg} / \mathrm{m}^{3}$ and $50-102 \mathrm{~kg} / \mathrm{m}^{3}$, respectively; therefore, it should not be directly discharged into the environment without appropriate treatment and/or valorisation [3]. As a result of stricter regulations for waste disposal and environmental concerns, cheese effluent management has become an important issue [1-4].

Two options for cheese whey management have normally been considered [3]. The first is the application of physicochemical treatments and filtration technologies to recover the most valuable compounds from cheese whey, i.e. proteins and lactose. Physicochemical treatments include thermal and isoelectric precipitation $[5,6]$ and protein precipitation [7], while filtration technologies involve the use of ultrafiltration membranes and reverse osmosis [2]. The second option relies on the application of biological treatments without valorisation, such as aerobic digestion, and with valorisation such as anaerobic digestion, lactose hydrolysis and fermentation [3]. Aerobic digestion consists of the degradation of the organic matter of whey at room temperature using short hydraulic retention times [8]. Anaerobic digestion is conducted to convert lactose into propionic acid, ethanol and lactose acetates [9]. Lactose hydrolysis is a preliminary step for other processes, as the number of microorganisms 
able to metabolise glucose and galactose are significantly higher than those that directly metabolise lactose. [4]. Cheese whey fermentation aims at the production of ethanol, lactic acid, and hydrogen $[10,11]$. The production of lactic acid has usually been carried out using the concentrated cheese whey coming from ultrafiltration [12-16]. The anaerobic fermentation produces a gas made up of a mixture of $\mathrm{H}_{2}, \mathrm{CO}_{2}$ and $\mathrm{CH}_{4}$ with a theoretical yield of $4 \mathrm{~mol} \mathrm{H}_{2} / \mathrm{mol}$ lactose. Different clostridium species [17] and facultative anaerobic species [18] have been used employing CSTR, batch, and UASB reactors [3]. COD reductions of around $80-90 \%$ and lactose consumption between 87 and $97 \%$ have been reported [17-22]. Shukla et al. [23] produced a probiotic beverage from whey blended with pineapple juice. The whey and pineapple juice were blended in four different proportions i.e. 80:20, 75:25, 70:30 and 65:35. The highest score for flavour, consistency, colour and appearance was given to the beverage containing whey and pineapple juice in the ratio of 65:35. The characteristics of whey-based fruit drinks, which make them widely acceptable to consumers in Europe, are described in the work of Prendergast [24]. In addition, methods of production, based on fermentation and on direct acidification, are also described.

When seeking different options for the management and valorisation of cheese whey, the use of thermochemical processes emerges as a novel route for the valorisation of this effluent. Among these, catalytic steam reforming and aqueous phase reforming are two challenging and very promising alternatives for the treatment of this wastewater. Steam reforming is one of the most widespread processes for the generation of a hydrogen-rich synthesis gas from organic compounds. This catalytic process, which is carried out at atmospheric pressure and at moderate temperatures $\left(400-700{ }^{\circ} \mathrm{C}\right)$, enables the organic matter of cheese whey to be transformed into a gas with a high hydrogen 
content, up to $70 \mathrm{vol} . \%$, with many different posterior applications [25]. In addition, it can decrease the carbon content of the original feedstock to appropriate levels for safe discharge into the environment. Aqueous phase reforming (APR) is a relatively new catalytic process carried out at quite low temperatures $\left(200-240{ }^{\circ} \mathrm{C}\right)$ and moderate pressures (30-50 bar), during which various liquid-gas-solid chemical reactions take place. The process allows the simultaneous production of different chemicals (gases and liquids) from an organic feedstock. The gas phase consists of a gas with a high $\mathrm{H}_{2}$ content. The liquid phase is a complex mixture of different organic compounds in water such as alcohols, ketones, acids, esters, aldehydes, furans, phenols, anhydro-sugars and other oxygenated compounds with different compositions depending on the operating conditions of the process and the nature of the feed [26-29]. Therefore, APR can be customised either for the production of gases, helping to reduce the BOD and COD values of the feed, or for the production of valuable liquids that can be used as starting platform molecules for other processes. In addition, the APR process dispenses with the need to vaporise the water and the organic compounds of the feedstock, thus reducing the energy requirements [30]. This versatility converts the process into a very promising tailor-made route for the treatment and valorisation of cheese whey effluents.

To the best of the authors' knowledge, there are no studies in the literature concerning the use of these two thermochemical processes for the valorisation of cheese whey. Furthermore, works dealing with the catalytic steam reforming or the aqueous phase reforming of sugars are extremely scarce. In a previous work Remón et al. [31] analysed the catalytic steam reforming of lactose, the major organic compound of cheese whey. Using a lactose concentration similar to that of cheese whey (5.5 wt.\%), maxima for the $\mathrm{CC}$ gas $(88 \%)$ and the proportion of $\mathrm{H}_{2}(67 \mathrm{vol} . \%)$ in the gas together with a carbon-free 
liquid stream were achieved at $586{ }^{\circ} \mathrm{C}$ using a spatial time of $16 \mathrm{~g}$ catalyst $\mathrm{min} / \mathrm{g}$ lactose. In addition, the process was energetically optimised, and it was found that the combustion of $20 \%$ of this gas could provide the energy necessary for the process.

As regards steam reforming of other oxygenated compounds, $\mathrm{Hu}$ and $\mathrm{Lu}$ [32] studied the catalytic steam reforming of glucose for $\mathrm{H}_{2}$ production, analysing the effect of the reaction time $(0-3 \mathrm{~h})$, temperature $\left(300-600^{\circ} \mathrm{C}\right)$ and steam to carbon $(\mathrm{S} / \mathrm{C})$ ratio $(3-9$ mol $\mathrm{H}_{2} \mathrm{O} / \mathrm{mol} \mathrm{C}$ ) on the process. Marquevich et al. [33] reported the effect of the temperature and $\mathrm{S} / \mathrm{C}$ ratio on the catalytic steam reforming of xylose, glucose and sucrose. Both studies reached the same conclusions. An increase in the temperature increases gas production and the yield to $\mathrm{H}_{2}$ and reduces char formation. The $\mathrm{S} / \mathrm{C}$ ratio plays a very important role in the process, decreasing solid formation and enhancing gas production, and therefore high $\mathrm{S} / \mathrm{C}$ ratios are necessary to ensure a high carbon conversion to gas. However, these sugars are unstable at high temperatures and decompose before reaching the catalytic bed. This leads to substantial char formation in the upper part of the reactor, thus decreasing the efficiency of the process. Tosti et al. [34] used a membrane reactor consisting of a dense self-supported Pd-Ag tube for the oxidative reforming of a mixture of ethanol in water containing traces of glycerol and acetic acid, which simulated a residue produced in the dairy industry. An optimum for $\mathrm{H}_{2}$ production was found at $400{ }^{\circ} \mathrm{C}$ and $200 \mathrm{kPa}$.

The aqueous phase reforming of sugars has been considered for xylitol, sorbitol and galactitol. Jiang et al. [35] studied the APR of xylitol for pentane production over Pt/HZSM-5 and Ni/HZSM-5 catalysts, analysing the effects of the temperature, pressure 
and metal loading on the xylitol conversion and pentane selectivity. The two latter variables augmented with an increase in the catalyst metal loading from 0 to $3 \mathrm{wt} . \%$ and decreased with a further increase up to $5 \mathrm{wt} . \%$. An increase in the reaction temperature from 180 to $240{ }^{\circ} \mathrm{C}$ at $4 \mathrm{MPa}$ increased the xylitol conversion from 30 to $80 \%$. At 240 ${ }^{\circ} \mathrm{C}$, an increase in the pressure from 2 to $4 \mathrm{MPa}$ increased the xylitol conversion from 61 to $80 \%$. Kirilin et al. [36] reported the APR of xylitol in a continuous fixed bed reactor over three catalysts: $\mathrm{Pt} / \mathrm{Al}_{2} \mathrm{O}_{3}, \mathrm{Pt} / \mathrm{TiO}_{2}$ and $\mathrm{Pt}-\mathrm{Re} / \mathrm{TiO}_{2}$. Higher conversions of xylitol were observed for the Pt-Re catalyst than for the two monometallic catalysts. Xi et al. [37] prepared different $\mathrm{M} / \mathrm{NbOPO}_{4}$ multifunctional catalysts $(\mathrm{M}=\mathrm{Pt}, \mathrm{Pd}, \mathrm{Ru}, \mathrm{Ir}, \mathrm{Rh}$ and Ni) for alkane production by the hydrodeoxygenation of sorbitol in aqueous solution. The activity of the catalysts decreased in the following order: $\mathrm{Pt}>\mathrm{Pd}>\mathrm{Rh}>\mathrm{Ru}>\mathrm{Ir}>$ Ni. Aiouache et al. [38] developed a path lumping kinetic model for the aqueous phase reforming of sorbitol. Paths of reforming and $\mathrm{CO}_{2}$ methanation were more important than decarbonylation and hydrodeoxygenation at small conversions for all the catalysts, whereas the hydrodeoxygenation-decarbonylation reactions towards alkanes were more competitive than the reforming reactions at high conversions.

Kirilin et al. [39] investigated the APR of xylitol and sorbitol using a $\mathrm{Pt} / \mathrm{Al}_{2} \mathrm{O}_{3}$ catalyst. Generally, higher yields and selectivity to hydrogen were observed for xylitol than for sorbitol. The maximum selectivity to $\mathrm{H}_{2}(83 \%)$ was achieved in the case of xylitol. Additionally, the yields to liquid products and hydrogen were higher in the case of xylitol compared to sorbitol due to the longer carbon chain in the latter substrate. Godina et al. [40] analysed the APR of sorbitol and galactitol over a $\mathrm{Pt} / \mathrm{Al}_{2} \mathrm{O}_{3}$ catalyst in a continuous fixed-bed reactor at $225^{\circ} \mathrm{C}$. The analysis of the gas and liquid phases 
obtained in the experiments showed almost the same behaviour and the same conversion for both substrates.

Given this background, this work analyses the valorisation by steam reforming and aqueous phase reforming of real cheese whey resulting from the production of fresh cow cheese. The influence of some of the most important operating conditions such as the temperature and spatial time has been investigated. In addition, a comparison has been established between the results obtained with cheese whey, filtered cheese whey and a lactose solution having a similar lactose concentration as cheese whey. For cheese whey valorisation, it is not only important to produce valuable chemicals from this waste, but also to come up with a carbon-free liquid stream that could be safely discharged into the environment. Therefore, the gas, liquid and solid production obtained in the experiments and the compositions of the gas and liquid phases have been exhaustively analysed. These two thermochemical processes have never before been considered for real cheese whey management, while works dealing with the steam reforming and aqueous phase reforming of sugars are very scarce. Hence, this work represents a challenging and novel investigation not only for the management and valorisation of cheese whey but also for the production of value-added chemicals from sugars or sugar-based streams.

\section{Materials and methods}

\subsection{Materials}

Two different Ni copecipitated catalysts were used for the valorisation experiments. A $\mathrm{Ni}-\mathrm{Co} / \mathrm{Al}-\mathrm{Mg}$ was selected for the steam reforming experiments. This catalyst has a 
$28 \%$ (relative atomic percentage) $\mathrm{Ni}$ expressed as $\mathrm{Ni} /(\mathrm{Ni}+\mathrm{Co}+\mathrm{Al}+\mathrm{Mg})$, an atomic $\mathrm{Mg} / \mathrm{Al}$ ratio of 0.26 and an atomic $\mathrm{Co} / \mathrm{Ni}$ ratio of 0.10 , with a $\mathrm{BET}$ surface area of about $132 \mathrm{~m}^{2} / \mathrm{g}$ [41]. A Ni-La/Al, having a 28\% (relative atomic percentage) of Ni expressed as $\mathrm{Ni} /(\mathrm{Ni}+\mathrm{Al}+\mathrm{La})$, an atomic $\mathrm{La} / \mathrm{Al}$ ratio of 0.035 and a BET surface area of $187 \mathrm{~m}^{2} / \mathrm{g}$ was used for the aqueous phase reforming experiments [42].

The cheese whey used for this work, provided by "Quesos La Pardina" (Zaragoza, Spain), was obtained as a by-product in the production of fresh cow milk cheese. The characterisation results of this feedstock, including the chemical composition, elemental analysis, Total Organic Carbon (TOC), density and $\mathrm{pH}$, are listed in Table 1. The chemical composition was calculated by means of a Gas Chromatography-Mass Spectrometry analysis, Karl Fischer titration and ash content. The ashes were characterised by XRD. This analysis revealed that they were made up of $\mathrm{KCl}$ and $\mathrm{CaCO}_{3}$. The properties of this whey are consistent with those reported in other works in the literature [1-4]. Some experiments have been conducted using filtered cheese whey and a lactose solution, and a comparison between the results obtained with the three feedstocks (cheese whey, treated cheese whey and lactose) was established under the same operating conditions. These conditions were selected having regard to the characteristics of the reforming processes as well as the limited amount of cheese whey available for the experiments. The cheese whey treatment consisted of an initial vacuum filtration and a subsequent centrifugation of the cheese whey to reduce the amount of proteins and fats. The elemental analysis of the filtered whey revealed a decrease in the proportion of $\mathrm{N}$ along with a decrease in the proportion of 2-propanamine in comparison with the original feedstock (Table 1). The lactose solution was prepared dissolving D-lactose monohydrate $\left(\mathrm{C}_{12} \mathrm{H}_{22} \mathrm{O}_{11} \cdot \mathrm{H}_{2} \mathrm{O}\right.$ Sigma Aldrich, CAS Number 
64044-51-5, Bio-Ultra $>99.5 \%$ HPLC) in Milli-Q water. A slightly higher

concentration of lactose was chosen for the comparison, having regard to the total amount of $\mathrm{C}$ in the real cheese whey due to the presence of other organics in the real feedstock. This lactose solution had a TOC of $23137 \mathrm{ppm}$, which is close to that of the real whey. The $\mathrm{S} / \mathrm{C}$ ratios of the cheese whey, the filter cheese whey and the lactose solution were $22.2,27.7$ and $27.3 \mathrm{~mol} / \mathrm{mol}$, respectively.

\subsection{Reforming installations}

The experimental installations used in the experiments were two microactivity units designed and built by PID (Process Integral Development Eng \& Tech, Spain). The unit for the catalytic steam reforming experiments consists of a small bench scale rig comprising a quartz fixed bed reactor of $25 \mathrm{~mm}$ in height and $9 \mathrm{~mm}$ inner diameter. The cheese whey, filtered cheese whey and lactose solutions were fed into the reactor with a HPLC pump (Gilson, model 307). $\mathrm{N}_{2}$ was used as a carrier gas to facilitate the feeding of the solutions, as well as an internal standard for gas quantification. Once inside the reactor, the feed down-flow passed through the catalytic bed, consisting of a mixture of catalyst and inert sand. The gaseous mixture passed to a condensation system consisting of a stainless steel vessel cooled by means of a Peltier thermoelectric cell where the condensable vapours were trapped. A system of several condensers was added after the Peltier unit to recover the liquid products at intervals of $1 \mathrm{~h}$ to analyse the evolution over time of the liquid phase. The permanent gases exiting the condensation system were analysed online with a micro gas chromatograph. More details concerning the setup can be found in our previous communications [41, 43, 44]. 
The APR reforming unit consists of a stainless steel tubular reactor with an inner diameter of $9 \mathrm{~mm}$, heated up by means of an electric furnace. The system pressure was reached with the aid of a micrometric valve that automatically adapts its position with the help of a rotor. A pressure gauge, located at the exit of the reactor, measured the pressure of the reaction section. A PDI control system was used to keep the reactor pressure constant during the experiments. The cheese whey and the lactose solutions were fed into the reactor by means of a HPLC pump (Gilson, model 307). The reaction products (gas and liquids) left the reactor from its upper part, passed through the valve, where they were depressurised, and arrived at the condensation system. This system consisted of several condensers where the liquid products were separated from the gas mixture at intervals of $1 \mathrm{~h}$. The gas mixture was made up of $\mathrm{N}_{2}$, used as an internal standard, and the different gaseous products formed during the aqueous phase reforming reaction. More details concerning the set-up can be found in our previous communications $[42,45]$.

An Agilent M3000 micro chromatograph equipped with thermal conductivity detectors (TCD) was used in both installations for the online analysis of the gas phase. The liquid fractions were collected and analysed offline with a gas chromatograph (Agilent 7890 GC-system, model G3440A) equipped with Flame Ionization (FID) and Mass Spectrometry (MS) detectors.

\subsection{Response variables and statistical analyses}

The effect of the operating conditions and the feed (cheese whey, filtered cheese whey or lactose) on the process was analysed for the following response variables: global lactose conversion (X lactose, \%), carbon conversion to gas, liquid and solid products 
(CC gas \%, CC liq \%, and CC sol \%), as well as the composition of the gas $\left(\mathrm{N}_{2}\right.$ and $\mathrm{H}_{2} \mathrm{O}$ free, vol.\% or mol.\%) and liquid (relative chromatographic area free of water and un-reacted lactose, \%). A semi-quantitative analysis was conducted to analyse the effect of the operating conditions on the composition of the liquids due to the high complexity of the liquid phases. Table 2 summarises the response variables and the analytical methods used for their calculation.

The effect of the temperature and the mass of catalyst/mass flow rate of carbon $\left(\mathrm{W} / \mathrm{m}_{\mathrm{C}}\right)$ were analysed during the catalytic steam reforming experiments. Different experiments were conducted at $450{ }^{\circ} \mathrm{C}$ and $600{ }^{\circ} \mathrm{C}$ using $\mathrm{W} / \mathrm{m}_{\mathrm{C}}$ ratios of 24 and $38 \mathrm{~g}$ catalyst min/g carbon for two hours. This temperature interval was selected having regard to the thermodynamics and energetic issues of the process [31]. The aqueous phase reforming experiments were conducted at $220^{\circ} \mathrm{C}$ and 44 bar for $1 \mathrm{~h}$. This temperature and pressure are usually used during the APR of organic compounds [42]. The effect of the $\mathrm{W} / \mathrm{m}_{\mathrm{C}}$ ratio $(60,95$ and $130 \mathrm{~g}$ catalyst/min $\mathrm{g}$ carbon) was analysed for cheese whey valorisation by APR.

All the experiments with cheese whey and lactose were performed at least in duplicate. The experimental results have been compared using a one-way analysis of variance (one-way ANOVA) and Fisher's least significant difference (LSD) test, both with 95\% confidence. The results of the ANOVA analyses are provided as p-values. P-values lower than 0.05 indicate that at least two values are significantly different. Furthermore, the LSD test was used to compare pairs of data. The results of the LSD tests are presented graphically in the form of LSD bars. To ensure significant differences between any pairs of data, their LSD bars must not overlap. 
Some of the used catalysts were characterised by X-Ray diffraction (XRD) and elemental analyses. XRD patterns of the used catalysts were obtained with a D-Max Rigaku diffractometer equipped with a $\mathrm{CuK} \alpha 1.2$ at a tube voltage of $40 \mathrm{kV}$ and current of $80 \mathrm{~mA}$. The measurements were carried out using continuous-scan mode with steps of $0.03^{\circ} / \mathrm{s}$ at Bragg's angles $(2 \theta)$ ranging from $5^{\circ}$ to $85^{\circ}$. The phases present in the samples were defined with reference to the JCPDS-International Centre for Diffraction Data 2000 database. From the elemental analysis, the CC coke and the amount of C deposited with respect to the amount of catalyst and organics reacted ( $\mathrm{mg} \mathrm{C} / \mathrm{g}$ catalyst $\mathrm{g}$ organics reacted) were calculated.

\subsection{Possible reaction networks}

\subsubsection{Cheese whey steam reforming}

Lactose steam reforming includes reforming, cracking and thermal decomposition reactions due to the instability of sugars at high temperatures $[32,33]$.

\section{1- Reforming reactions:}

Steam reforming of the oxygenated compounds:

$\mathrm{C}_{\mathrm{n}} \mathrm{H}_{\mathrm{m}} \mathrm{O}_{\mathrm{k}}+(\mathrm{n}-\mathrm{k}) \mathrm{H}_{2} \mathrm{O} \Leftrightarrow \mathrm{n} \mathrm{CO}+(\mathrm{n}+\mathrm{m} / 2-\mathrm{k}) \mathrm{H}_{2}$

Water gas shift (WGS) reaction:

$$
\mathrm{CO}+\mathrm{H}_{2} \mathrm{O} \Leftrightarrow \mathrm{CO}_{2}+\mathrm{H}_{2} \quad\left(\Delta \mathrm{H}_{298 \mathrm{~K}}=-41 \mathrm{~kJ} / \mathrm{mol}\right)
$$

Methane steam reforming and dry reforming:

$$
\begin{array}{ll}
\mathrm{CH}_{4}+\mathrm{H}_{2} \mathrm{O} \Leftrightarrow \mathrm{CO}+3 \mathrm{H}_{2} & \left(\Delta \mathrm{H}_{298 \mathrm{~K}}=206 \mathrm{~kJ} / \mathrm{mol}\right) \\
\mathrm{CH}_{4}+2 \mathrm{H}_{2} \mathrm{O} \Leftrightarrow \mathrm{CO}_{2}+4 \mathrm{H}_{2} & \left(\Delta \mathrm{H}_{298 \mathrm{~K}}=165 \mathrm{~kJ} / \mathrm{mol}\right) \\
\mathrm{CH}_{4}+\mathrm{CO}_{2} \Leftrightarrow 2 \mathrm{CO}+2 \mathrm{H}_{2} & \left(\Delta \mathrm{H}_{298 \mathrm{~K}}=247 \mathrm{~kJ} / \mathrm{mol}\right)
\end{array}
$$


Boudouard reaction:

$2 \mathrm{CO} \Leftrightarrow \mathrm{CO}_{2}+\mathrm{C} \quad\left(\Delta \mathrm{H}_{298 \mathrm{~K}}=-173 \mathrm{~kJ} / \mathrm{mol}\right)$

(Eq. 6)

2- Thermal decomposition and cracking reactions

$\mathrm{C}_{\mathrm{n}} \mathrm{H}_{\mathrm{m}} \mathrm{O}_{\mathrm{k}} \rightarrow$ Liquids $\left(\mathrm{C}_{\mathrm{x}} \mathrm{H}_{\mathrm{y}} \mathrm{O}_{\mathrm{z}}\right)+\mathrm{Gas}\left(\mathrm{H}_{2}, \mathrm{CO}, \mathrm{CO}_{2}, \mathrm{CH}_{4}, \ldots\right)+$ carbon

\subsubsection{Cheese whey aqueous phase reforming}

During the APR of cheese whey, various liquid-gas-solid chemical reactions take place. These include cracking and reforming reactions to generate hydrogen, dehydrogenation of alcohols/hydrogenation of carbonyls, deoxygenation and hydrogenolysis as well as cyclisation reactions. Gases, mainly $\mathrm{H}_{2}$ and $\mathrm{CO}$, are produced by the thermal decomposition and/or reforming reactions of the lactose and all the liquid intermediates (Eq.1) as well as by all the decarbonylation reactions that release CO. In addition, the WGS reaction (Eq.2), the methanation reaction and the inverse of methane steam reforming reactions (Eq.3-4) are also possible, explaining the presence of $\mathrm{CO}_{2}$ and $\mathrm{CH}_{4}$ in the gas phase $[32,33]$.

\section{Results and discussion}

\subsection{Catalytic steam reforming}

\subsubsection{Lactose conversion and carbon conversion to gas, liquid and solid products}

A complete global lactose conversion (X lactose) was achieved in all the experiments, indicating that all the lactose was converted into gas, liquid and solid products. The $\mathrm{C} / \mathrm{O}$ 
ratio close to 1 of lactose allows complete conversion to be achieved even at the lowest temperature used in this work $[32,46]$. Complete conversions were achieved at temperatures higher than $500{ }^{\circ} \mathrm{C}$ in the work of $\mathrm{Hu}$ et al. [32] during the steam reforming of glucose. Fig. 1 shows the $\mathrm{CC}$ gas, $\mathrm{CC}$ liq and $\mathrm{CC}$ sol obtained for the steam reforming experiments in two intervals of one hour each. The statistical analysis reveals significant differences between the results obtained in the experiments for the CC gas, CC liq and CC sol (p-values $<0.001)$.

The CC gas obtained when feeding cheese whey is low $(<35 \%)$ regardless of the temperature $\left(450-600{ }^{\circ} \mathrm{C}\right)$ or the $\mathrm{W} / \mathrm{m}_{\mathrm{C}}$ ratio (24-38 g catalyst min/g carbon) employed in the experiments. This low $\mathrm{CC}$ gas is the consequence of the high $\mathrm{CC}$ sol due to char formation in the upper part of the reactor. Sugar molecules are unstable at the temperatures of this process $\left(450-600{ }^{\circ} \mathrm{C}\right)$ and quickly decompose through pyrolysis, leading to the formation of char particles and gases [33]. This char formation is the consequence of an incomplete vaporisation of the feed and has been reported in other works dealing with the steam reforming of lactose [31] and other sugars [32, 33, 44]. In addition, neither the temperature nor the $\mathrm{W} / \mathrm{m}_{\mathrm{C}}$ ratio affects the $\mathrm{CC}$ gas or the $\mathrm{CC}$ sol when feeding real cheese whey to the reactor. Increases in the $\mathrm{CC}$ gas and decreases in the CC sol over time take place during the reforming of cheese whey. The accumulation of the char in the upper part of the reactor might have a positive catalytic effect on the pyrolysis and/or cracking reactions of lactose and its liquid intermediates. Char obtained from the pyrolysis of different biomass materials has been reported to have catalytic activity for the reforming and cracking of different hydrocarbons [47-53], which accounts for the drops over time observed for the $\mathrm{CC}$ sol $[32,33]$ and the increases in the CC gas. 
In addition, the presence of salts in the cheese whey might be responsible for the increase and decrease in the $\mathrm{CC}$ gas and $\mathrm{CC}$ sol over time, respectively. Inorganic salts in a water solution decrease the evaporation rate of the other organic compounds [54], which might result in a higher formation of carbonaceous deposits (char) [55]. The accumulation of char particles in the upper part of the reactor hinders the vaporisation of the feed as the atomisation system is not as effective when the liquid comes into contact with solid particles, leading to bigger droplet sizes. Consequently, the evaporation takes places at lower heating rates. This enhances the formation of more carbonaceous deposits, augmenting the formation of char over time [55]. However, as the reaction advances and salts progressively accumulate inside the reactor, their presence exerts a positive catalytic effect $[56,57]$, aiding the gasification of these carbon deposits, which experimentally leads to a decrease over time in the CC sol. The accumulation of salts in the catalyst bed was corroborated at the end of the experiments.

The results obtained with cheese whey have been compared with those obtained when feeding a lactose solution [31] and a filtered cheese whey (F.C. Whey). The comparison between cheese whey and lactose reveals that higher $\mathrm{CC}$ gas and lower $\mathrm{CC}$ sol are obtained with lactose for the two temperatures and the two $\mathrm{W} / \mathrm{m}_{\mathrm{C}}$ ratios tested. These differences are noticeably marked at high temperatures and using a high $\mathrm{W} / \mathrm{m}_{\mathrm{C}}$ ratio. For this lactose solution, an increase in the temperature increases and decreases the $\mathrm{CC}$ gas and CC sol, respectively. High temperatures not only facilitate the vaporisation of the feed, decreasing the formation of solid carbon, but also favour the reforming process due to its endothermic nature $[32,33]$, thus increasing and decreasing the $\mathrm{CC}$ gas and $\mathrm{CC}$ sol, respectively. In addition, an increase in the $\mathrm{W} / \mathrm{m}_{\mathrm{C}}$ ratio increases the $\mathrm{CC}$ gas 
and decreases the $\mathrm{CC}$ sol due to the positive catalytic effect on reforming and gasification reactions. This effect is particularly marked at low temperatures, as high temperatures kinetically promote the reforming reactions, thus partially masking the positive effect of the catalyst.

The evolution over time of these two variables is different than that observed for cheese whey. During the reforming of lactose, two trends take place depending on the $\mathrm{W} / \mathrm{m}_{\mathrm{C}}$ ratio at low temperature $\left(450^{\circ} \mathrm{C}\right)$. For $24 \mathrm{~g}$ catalyst $\mathrm{min} / \mathrm{g}$ carbon, the $\mathrm{CC}$ gas and $\mathrm{CC}$ sol decrease over time. The decrease in the $\mathrm{CC}$ gas might be the consequence of the deactivation of the catalyst $[32,33]$, while the decrease in the $\mathrm{CC}$ sol is accounted for by the pyrolysis of the char resulting from the incomplete vaporisation of the feed. These two developments lead to an increase in the $\mathrm{CC}$ liq over time. For $38 \mathrm{~g}$ catalyst $\mathrm{min} / \mathrm{g}$ carbon, the $\mathrm{CC}$ gas and $\mathrm{CC}$ sol remain steady during the two hours of reaction. This steady evolution also takes place at $600{ }^{\circ} \mathrm{C}$ when a $\mathrm{W} / \mathrm{m}_{\mathrm{C}}$ ratio of $24 \mathrm{~g}$ catalyst $\mathrm{min} / \mathrm{g}$ carbon is used. Conversely, for $38 \mathrm{~g}$ catalyst $\mathrm{min} / \mathrm{g}$ carbon at $600{ }^{\circ} \mathrm{C}$ the $\mathrm{CC}$ gas slightly increases and the $\mathrm{CC}$ sol decreases. An elevated temperature and a high $\mathrm{W} / \mathrm{m}_{\mathrm{C}}$ ratio helps to prevent catalyst deactivation by coking, increases the reforming and the evaporation rates, and aids the gasification of the char.

The presence of fats and proteins in cheese whey might be partially responsible for the lower CC gas and the $\mathrm{CC}$ sol obtained with cheese whey than with lactose. The presence of these compounds might increase the formation of carbonaceous deposits due to their relatively high molecular mass. An increase in the molecular mass leads to bigger droplet sizes, causing the evaporation of the feed to take place at lower heating rates, increasing the $\mathrm{CC}$ sol [55]. Therefore, the cheese whey was filtered and 
centrifuged to reduce the fat and proteins in the whey, and additional experiments were conducted with this filtered cheese whey at $450{ }^{\circ} \mathrm{C}$ and $600{ }^{\circ} \mathrm{C}$ using a W/m $\mathrm{C}$ ratio of 24 g catalyst $\mathrm{min} / \mathrm{g}$ carbon.

During the first hour of reaction, the $\mathrm{CC}$ gas obtained with this filtered solution was slightly higher than that obtained when feeding the original cheese whey, but still lower than the conversion achieved with lactose. A lower CC sol was obtained with the filtered cheese whey in comparison with the original feedstock. However, the solid production was still higher than that obtained when feeding lactose and there was an increase over time of the $\mathrm{CC}$ gas together with a decrease in the $\mathrm{CC}$ sol. These results seem to indicate that fats and proteins contribute to increasing the solid formation, but the main factor responsible for the substantial formation of solid is the presence of salts in the cheese whey, as remarked above.

The CC liq is relatively low for the vast majority of experiments. Specifically, CC liq lower than $1 \%$ was obtained for the experiments performed with the original and the filtered cheese whey. This indicates that the temperature range $\left(450-600^{\circ} \mathrm{C}\right)$ and the relatively high spatial times used in the experiments enhance gas formation from the vaporised part of the feed, thus producing an almost carbon free liquid condensate, which is very important for cheese whey management. The highest CC liq was obtained with lactose using a relatively low $\mathrm{W} / \mathrm{m}_{\mathrm{C}}$ ratio ( $24 \mathrm{~g}$ catalyst $\mathrm{min} / \mathrm{g}$ carbon). This denotes that this amount of catalyst is not high enough to convert the evaporated part of the feed into gases, especially at low temperature $\left(450^{\circ} \mathrm{C}\right)$. An increase in the temperature or in the $\mathrm{W} / \mathrm{m}_{\mathrm{C}}$ ratio increases the formation of gas from the organic compounds present in the feed, thus reducing the CC liq. 


\subsubsection{Gas composition}

The gas phase consists of a mixture of $\mathrm{H}_{2}, \mathrm{CO}_{2}, \mathrm{CO}$ and $\mathrm{CH}_{4}$. Fig. 2 shows the gas composition obtained for the different experiments in two intervals of $1 \mathrm{~h}$ each. $\mathrm{H}_{2}$ (5972 vol.\%) and $\mathrm{CO}_{2}(28-38$ vol.\%) are the compounds with the greatest proportion in the gas phase, while the concentrations of $\mathrm{CO}\left(<9\right.$ vol.\%) and $\mathrm{CH}_{4}(<3$ vol.\%) in the gas are much lower.

The reforming temperature and $\mathrm{W} / \mathrm{m}_{\mathrm{C}}$ ratio do not significantly influence the proportion of $\mathrm{H}_{2}$ and $\mathrm{CO}_{2}$ in the gas during the first hour of reaction when real cheese whey is catalytically reformed. This development accounts for the substantial formation of $\mathrm{C}$ deposits that lowers the amount of $\mathrm{C}$ in the gas, thus increasing the effective $\mathrm{W} / \mathrm{m}_{\mathrm{C}}$ ratio for the vaporised part of the feed. This masks the positive effect of the temperature and $\mathrm{W} / \mathrm{m}_{\mathrm{C}}$ ratio on the gas composition and allows a gas with a high proportion of $\mathrm{H}_{2}$ to be achieved at the lowest temperature considered in this work while employing a $\mathrm{W} / \mathrm{m}_{\mathrm{C}}$ ratio as low as $24 \mathrm{~g}$ catalyst $\mathrm{min} / \mathrm{g}$ carbon.

However, these two operating variables exert a significant influence on the evolution of these two gases over time. The proportion of $\mathrm{H}_{2}$ decreases while that of $\mathrm{CO}_{2}$ increases after the first hour of reaction due to the progressive deactivation of the catalyst.

Comparing the experiments conducted at the same temperature shows that the lower the $\mathrm{W} / \mathrm{m}_{\mathrm{C}}$ ratio, the greater the reductions in the proportion of $\mathrm{H}_{2}$ over time. High $\mathrm{W} / \mathrm{m}_{\mathrm{C}}$ ratios allow a greater amount of active catalyst in the bed, thus minimising the decay observed for the proportion of $\mathrm{H}_{2}$ in the gas. The temperature exerts a positive catalytic effect on the gasification of these carbon deposits, which helps to prevent catalyst 
deactivation. Therefore, the decay observed in the proportion of $\mathrm{H}_{2}$ over time is lower at 600 than at $450{ }^{\circ} \mathrm{C}$. In addition, this decay does not take place when using a high temperature and $\mathrm{W} / \mathrm{m}_{\mathrm{C}}$ ratio.

During the reforming of lactose, an increase in the temperature from 450 to $600{ }^{\circ} \mathrm{C}$ increases the concentrations of $\mathrm{H}_{2}$ and $\mathrm{CO}_{2}$ in the gas for a W/m ratio of $24 \mathrm{~g}$ catalyst $\mathrm{min} / \mathrm{g}$ carbon. This is the consequence of two developments, the increase in the amount of $\mathrm{C}$ in the gas phase with the temperature and the endothermic character of lactose steam reforming. The increase in the proportion of $\mathrm{H}_{2}$ has also been reported in other works dealing with steam reforming of other saccharides $[32,33]$. When the $\mathrm{W} / \mathrm{m}_{\mathrm{C}}$ ratio increases up to $38 \mathrm{~g}$ catalyst $\mathrm{min} / \mathrm{g}$ carbon, the effect of the temperature on the proportions of $\mathrm{H}_{2}$ and $\mathrm{CO}_{2}$ in the gas is not significant as the positive kinetic effect of the catalyst is higher than the effect of the temperature.

In addition, the effect of the $\mathrm{W} / \mathrm{m}_{\mathrm{C}}$ is only significant at low temperature $\left(450^{\circ} \mathrm{C}\right)$ as the positive effect of the temperature masks the effect of the $\mathrm{W} / \mathrm{m}_{\mathrm{C}}$ ratio at $600{ }^{\circ} \mathrm{C}$. At 450 ${ }^{\circ} \mathrm{C}$ an increase in the $\mathrm{W} / \mathrm{m}_{\mathrm{C}}$ ratio increases the proportion of $\mathrm{H}_{2}$ and $\mathrm{CO}_{2}$ in the gas. The presence of the catalyst promotes the gasification of the carbon deposits and favours a greater spread of the reforming reaction, thus increasing the proportion of $\mathrm{H}_{2}$ and $\mathrm{CO}_{2}$. For the experiments conducted with lactose, the proportions of $\mathrm{H}_{2}$ and $\mathrm{CO}_{2}$ show a steady composition during the 2 hours of experiment. This indicates that a lower catalyst deactivation occurs when feeding lactose than during the reforming of cheese whey and is in good agreement with the lower solid production obtained in the reforming of the former than the latter. 
The filtration of the cheese whey marginally changes the proportions of $\mathrm{H}_{2}$ and $\mathrm{CO}_{2}$ in the gas. Specifically, a slightly higher proportion of $\mathrm{H}_{2}$ and a lower concentration of $\mathrm{CO}_{2}$ in the gas are obtained with the filtered whey at $450{ }^{\circ} \mathrm{C}$ using a $\mathrm{W} / \mathrm{m}_{\mathrm{C}}$ ratio of $24 \mathrm{~g}$ catalyst $\mathrm{min} / \mathrm{g}$ carbon. This result is the consequence of the increase in the proportion of $\mathrm{C}$ in the gas phase, as explained above, due to the reduction of fats and proteins in the whey, which decreases solid formation. Conversely, non-statistically significant differences are found in the proportions of $\mathrm{H}_{2}$ and $\mathrm{CO}_{2}$ in the gas between the filtered and the original cheese whey at $600{ }^{\circ} \mathrm{C}$. High temperatures promote the vaporisation of the feed, thus reducing the positive effect that the elimination of proteins and fats from the whey exerts on the vaporisation of the feed.

These results indicate that a $\mathrm{H}_{2}$ rich gas can be obtained from the valorisation of cheese whey and a lactose solution by steam reforming. At $600{ }^{\circ} \mathrm{C}$ and using a $\mathrm{W} / \mathrm{m}_{\mathrm{C}}$ ratio of $38 \mathrm{~g}$ catalyst min/g carbon, the overall 2 hour $\mathrm{H}_{2}$ yields obtained from the treatment of cheese whey and lactose are as follows: 11.5 and $21.5 \mathrm{~mol} \mathrm{H}_{2} / \mathrm{mol}$ lactose. The $\mathrm{H}_{2}$ yield obtained with pure lactose is close to the theoretical maximum of the process $(24 \mathrm{~mol}$ $\mathrm{H}_{2} /$ mol lactose). In addition, for both cheese whey and lactose, the $\mathrm{H}_{2}$ yield is higher than those obtained in anaerobic fermentation ( $4 \mathrm{~mol} \mathrm{H}_{2} / \mathrm{mol}$ lactose) or anaerobic fermentation plus photo-fermentation with L-malic acid (2-10 $\mathrm{mol} \mathrm{H}_{2} / \mathrm{mol}$ lactose).

The concentrations of $\mathrm{CO}$ and $\mathrm{CH}_{4}$ in the gas are relatively low, and lesser differences were found between the experiments conducted with cheese whey, filtered cheese whey and lactose. This indicates a greater spread of the water gas shift and methanation reactions as the relatively high $\mathrm{S} / \mathrm{C}$ ratios used help to shift the WGS and methane reforming reactions towards the formation of $\mathrm{H}_{2}$ [27]. The proportion of $\mathrm{CO}$ in the gas 
obtained during the first hour of reaction in the experiments conducted with cheese whey is very low $(<2$ vol. $\%)$, probably due to the shift of the water gas shift reaction towards $\mathrm{H}_{2}$ and $\mathrm{CO}_{2}$. The low amount of $\mathrm{C}$ in the gas phase increases the effective $\mathrm{W} / \mathrm{m}_{\mathrm{C}}$ ratio for the vaporised part of the feed, thus kinetically shifting the water gas shift reaction towards $\mathrm{H}_{2}$ and $\mathrm{CO}_{2}$. However, an increase in the proportion of $\mathrm{CO}$ in the gas over time occurs due to the progressive deactivation of the catalyst. The lower the $\mathrm{W} / \mathrm{m}_{\mathrm{C}}$ ratio, the sharper the increase over time in the proportion of $\mathrm{CO}$, as high $\mathrm{W} / \mathrm{m}_{\mathrm{C}}$ ratios can partially compensate for catalyst deactivation. For $24 \mathrm{~g}$ catalyst min/g carbon, the higher the temperature, the sharper is the increase over time in the proportion of $\mathrm{CO}$ in the gas. The water gas shift reaction is exothermic; therefore, low temperatures produce a greater spread of the water gas shift reaction, thus decreasing the proportion of CO.

In the experiments conducted with the filtered cheese whey, the initial proportion of $\mathrm{CO}$ in the gas is very low and increases with time. However, non-significant differences are detected for this gas between the filtered and the real whey. As regards the use of lactose in the process, significant differences between cheese whey and lactose are only found for the experiments conducted using a low $\mathrm{W} / \mathrm{m}_{\mathrm{C}}$ ratio $(24 \mathrm{~g}$ catalyst $\mathrm{min} / \mathrm{g}$ carbon). At $450{ }^{\circ} \mathrm{C}$ a gas with a greater proportion of $\mathrm{CO}$ is obtained during the reforming of lactose compared with cheese whey. At low temperature and using a low $\mathrm{W} / \mathrm{m}_{\mathrm{C}}$ ratio, a substantial amount of solid is produced during the reforming of cheese whey. This decreases the content of $\mathrm{C}$ in the gas phase thus allowing a greater shift of the water gas shift reaction to be achieved with the same amount of catalyst in the bed. The proportion of $\mathrm{CO}$ in the gas decreases when increasing the temperature. At low temperatures $\left(450^{\circ} \mathrm{C}\right)$, lactose is thermally decomposed into a gas with a high 
proportion of $\mathrm{CO}$ and $\mathrm{CO}_{2}$ [32]. The proportion of $\mathrm{CO}$ in the gas decreases towards its thermodynamic value when increasing the temperature due to the prevalence of reforming over thermal decomposition, producing a greater shift of the water gas shift reaction. In general, an increase in the $\mathrm{W} / \mathrm{m}_{\mathrm{C}}$ decreases the relative amount of $\mathrm{CO}$ in the gas due to the greater spread of the water gas shift reaction. For $38 \mathrm{~g}$ catalyst $\mathrm{min} / \mathrm{g}$ carbon, these differences are not observed due to the positive kinetic effect of the catalyst on the water gas shift reaction.

The proportion of $\mathrm{CH}_{4}$ in the gas during the first hour of experiment is very low $(<1$ vol.\%), which indicates that methane production from lactose is not favoured at the temperature range considered $\left(450-600^{\circ} \mathrm{C}\right)$. The highest proportion of $\mathrm{CH}_{4}$ in the gas (3.5 vol.\%) was achieved for the reforming of cheese whey using a low $\mathrm{W} / \mathrm{m}_{\mathrm{C}}$ ratio $(24$ g catalyst $\mathrm{min} / \mathrm{g}$ carbon) during the second hour of reaction. This increase in the concentration of $\mathrm{CH}_{4}$ in the gas is the consequence of the progressive deactivation of the catalyst, which hinders the methane steam reforming reactions, thus increasing the proportion of $\mathrm{CH}_{4}$ in the gas $[25,41,58]$.

\subsubsection{Liquid composition}

The liquid phase obtained during the steam reforming experiments is made up of a mixture of aldehydes (acetaldehyde and propanal), ketones (2-propanone), carboxylic acids (acetic and propionic acids), sugars (levoglucosan and D-alose), furans (furfural, 2-furancarboxaldehyde and 2,5-furandicarboxaldehyde), alcohols (ethanol, propanol and cyclic alcohols) and phenolic compounds (phenol and methyl-phenols). The presence of these compounds in the liquid phase is the result of the thermal decomposition of lactose and the incomplete reforming of lactose and its liquid 
intermediates. All these reaction intermediates have a high tendency to form coke and char (especially sugars, furans and aromatic species) [44, 59-62] which explains the high $\mathrm{CC}$ sol obtained experimentally. Figs. $3 \mathrm{a}$ and $\mathrm{b}$ plot the relative amounts of each of the different families of liquid compounds for the different experiments obtained during the first and second hour of experiment, respectively, together with the results of the Fischer's LSD test.

During the first hour of reaction, the liquid phase obtained during the reforming of cheese whey is made up of phenolic compounds when a $\mathrm{W} / \mathrm{m}_{\mathrm{C}}$ ratio of $24 \mathrm{~g}$ catalyst $\mathrm{min} / \mathrm{g}$ carbon is used, while a liquid condensate free of organic compounds is obtained for $38 \mathrm{~g}$ catalyst $\mathrm{min} / \mathrm{g}$ carbon. Phenols are end products of lactose thermal decomposition. The high CC sol achieved in the experiments conducted with cheese whey increases the effective $\mathrm{W} / \mathrm{m}_{\mathrm{C}}$ ratio. This increases the $\mathrm{CC}$ gas and produces an almost-free liquid condensate. Given that reforming of the aromatic compounds is thermodynamically less favoured than that of the light oxygenated liquid intermediates due to the stronger $\mathrm{C}-\mathrm{C}$ bonds involved [63], the liquid has a high concentration of phenolic compounds, which are less likely to evolve towards gas formation by reforming. An increase in the $\mathrm{W} / \mathrm{m}_{\mathrm{C}}$ ratio from 24 to $38 \mathrm{~g}$ catalyst $\mathrm{min} / \mathrm{g}$ carbon promotes the reforming of the phenolic compounds, and carbon free liquid condensate is obtained.

The comparison between the liquid condensates obtained from cheese whey and lactose shows a lower proportion of phenols and a higher concentration of intermediate liquid products (aldehydes, ketones, alcohols and carboxylic acids) for lactose than for cheese whey due to the lower carbon formation for the latter than for the former feedstock. 
This char formation lowers the amount of $\mathrm{C}$ in the gas, thus increasing the effective $\mathrm{W} / \mathrm{m}_{\mathrm{C}}$ ratio. An increase in the $\mathrm{W} / \mathrm{m}_{\mathrm{C}}$ ratio during the steam reforming of lactose decreases the relative amount of intermediate compounds due to the positive effect of the catalyst on the process. At $450{ }^{\circ} \mathrm{C}$ this increase leads to a sharp increase in the relative amount of carboxylic acids, while at $600{ }^{\circ} \mathrm{C}$ the proportion of phenols increases very sharply, as high temperatures shift the composition of the liquid phase towards end products. Very interestingly, significant differences between the composition of the liquid phase obtained with the real and the filtered cheese whey were not observed.

As regards the evolution of the liquid phase over time, the comparison between Figs. 3 a and $\mathrm{b}$ shows little variation in the chemical composition of the liquid phase, probably due to the low amount of liquid products produced in the experiments. The minor variations observed are accounted for by a decrease in the proportion of phenols and a decrease in the relative amount of ketones, probably due to catalyst deactivation. However, due to the low CC liq obtained in the experiments, these variations are not important from a practical point of view.

\subsection{Catalytic aqueous phase reforming}

\subsubsection{Lactose conversion and carbon conversion to gas, liquid and solid products}

A complete global lactose conversion (X lactose) was achieved in all the experiments, indicating that all the lactose was converted into gas, liquid and solid products, due to the $\mathrm{C} / \mathrm{O}$ ratio of this sugar $[32,46]$. The experiments were initially planned for 2 hours. However, the pressure significantly increased over the set point after the first hour of experiment due to the accumulation of char particles and non-soluble water compounds 
in the upper part of the reactor and the micrometric valve. Therefore, the experiments were run for $1 \mathrm{~h}$. Fig. 4 shows the overall $\mathrm{CC}$ gas, $\mathrm{CC}$ liq and $\mathrm{CC}$ sol obtained in the experiments. In addition, the initial $\mathrm{CC}$ gas $(\mathrm{t}=0 \mathrm{~h})$, obtained once the steady state was achieved, is also plotted in Fig. 4 a to study the evolution of the gas phase over time. This study was not possible for the $\mathrm{CC}$ liq and $\mathrm{CC}$ sol as the liquid condensates were recovered at intervals of $1 \mathrm{~h}$ each.

The statistical analysis reveals significant differences between the results obtained in the experiments for the CC gas, CC liq and CC sol (p-values $<0.001)$. The CC gas obtained during the aqueous phase reforming of cheese whey is relatively low $(25 \%)$, which indicates that gas production from cheese whey is not favoured under the reaction conditions tested in this work $\left(\mathrm{T}=220^{\circ} \mathrm{C}\right.$ and $\mathrm{P}=44$ bar). This is in good agreement with other works studying the APR of xylose and sorbitol $[35,39,64]$. In these works, the low gas productions (25-35\%) were obtained between 200 and $240{ }^{\circ} \mathrm{C}$. The comparison between the experiments conducted with cheese whey and lactose reveals that lower $\mathrm{CC}$ gas and higher $\mathrm{CC}$ sol are obtained with the former than with the latter. This lower gas production from cheese whey is the consequence of the high formation of char. In addition, the reduction of the amount of fats and proteins (filtered cheese whey) resulted in a reduction in char formation and in an increase in the $\mathrm{CC}$ gas. However, lower CC gas and higher CC sol were obtained with this treated whey in comparison with those obtained using lactose, which suggests that proteins and fats are partially responsible for the formation of char.

Sugar molecules are unstable at the temperatures used in this process and quickly decompose through pyrolysis, leading to the formation of char particles and gases [33]. 
This solid residue (char) obtained from the thermal decomposition of sugars is made up of polymerised degradation products such as humic acids and large organic compounds ranging from $\mathrm{C}_{8}$ to $\mathrm{C}_{15}[39,65-70]$. The formation of these macromolecules can occur from furfural and 5-hydroxymethyl-2-furancarboxaldehyde obtained from lactose dehydration, via aldol addition followed by condensation or polymerisation among themselves. Furthermore, both lactose monomers (glucose and galactose) can react with other liquid intermediates such as 5-hydroxymethyl-2-furancarboxaldehyde by crosspolymerisation $[65-67,69]$. The presence of salts in the cheese whey promotes the dehydration reactions $[71,72]$ of glucose and galactose thus increasing the proportion char precursors. This accounts for the greater solid and lower gas production during the reforming of cheese whey than for lactose and suggests that salts are one of the principal factors responsible for the great amount of char produced during the treatment of cheese whey by APR.

The $\mathrm{W} / \mathrm{m}_{\mathrm{C}}$ ratio exerts a significant influence on the $\mathrm{CC}$ gas during the APR of cheese whey. An increase from 60 to $130 \mathrm{~g}$ catalyst $\mathrm{min} / \mathrm{g}$ carbon significantly increases the $\mathrm{CC}$ gas and decreases the $\mathrm{CC}$ sol. This variable positively influences the $\mathrm{CC}$ gas due to its positive kinetic effect on cracking and reforming reactions [42]. In addition, an increase in the $\mathrm{W} / \mathrm{m}_{\mathrm{C}}$ ratio hinders char formation and favours carbon gasification, helping to decrease the $\mathrm{CC}$ sol.

The evolution of the CC gas over time displays significant drops. These drops are greater for the real and filtered cheese whey than for the lactose solution. The presence of salts favours dehydration reactions [71, 72], favouring condensation and crosspolymerisation reactions leading to the formation of humic acids and large organic 
compounds $[39,65-70]$. This increases the formation of coke and char, thus increasing catalyst deactivation and lowering gas formation over time.

A relatively high CC liq (30-45\%) was obtained during the APR of cheese whey. The high formation of solid during the processing of cheese whey decreases the formation of valuable liquid products. The comparison between the $\mathrm{CC}$ liq obtained for cheese whey and lactose reveals a lower $\mathrm{CC}$ liq for the former than for the latter due to the lower amount of char produced during the APR of lactose. Very interestingly, the reduction of the amount of fats and proteins by filtration does not significantly influence liquid production due to the compensatory effect of two developments: higher gas formation and lower solid production. The $\mathrm{W} / \mathrm{m}_{\mathrm{C}}$ ratio exerts a significant influence on the $\mathrm{CC}$ liq. An increase in the $\mathrm{W} / \mathrm{m}_{\mathrm{C}}$ ratio from 60 to $95 \mathrm{~g}$ catalyst $\mathrm{min} / \mathrm{g}$ carbon increases the liquid production from cheese whey. However, a further increase up to $130 \mathrm{~g}$ catalyst $\mathrm{min} / \mathrm{g}$ lactose decreases the liquid production as high $\mathrm{W} / \mathrm{m}_{\mathrm{C}}$ ratios favour gas production from the liquid intermediates obtained during APR [42]. When reforming lactose, an increase in the $\mathrm{W} / \mathrm{m}_{\mathrm{C}}$ ratio from 60 to $95 \mathrm{~g}$ catalyst $\mathrm{min} / \mathrm{g}$ carbon during the APR of lactose decreases the $\mathrm{CC}$ liq due to the increase observed in gas production.

\subsubsection{Gas composition}

The gas phase consists of a mixture of $\mathrm{H}_{2}, \mathrm{CO}_{2}, \mathrm{CO}$ and $\mathrm{CH}_{4}$. Fig. 5 plots the gas composition at the beginning of the experiment (once the steady state has been reached, $\mathrm{t}=0 \mathrm{~h})$ as well as the overall values obtained for the first hour of experiment $(\mathrm{t}=1 \mathrm{~h})$. The compounds present in the greatest proportions in the gas phase are $\mathrm{H}_{2}$ (11-33 
vol.\%), $\mathrm{CO}_{2}$ (49-72 vol.\%) and $\mathrm{CH}_{4}$ (7-17 vol.\%), while the concentration of $\mathrm{CO}(<2$ vol.\%) in the gas is much lower.

An increase in the $\mathrm{W} / \mathrm{m}_{\mathrm{C}}$ ratio from 60 to $95 \mathrm{~g}$ catalyst $\mathrm{min} / \mathrm{g}$ carbon during the APR of cheese whey augments the initial proportion of $\mathrm{H}_{2}$ and decreases the concentration of $\mathrm{CO}_{2}$ in the gas. However, a further increase in the $\mathrm{W} / \mathrm{m}_{\mathrm{C}}$ ratio up to $130 \mathrm{~g}$ catalyst $\mathrm{min} / \mathrm{g}$ carbon does not significantly modify the initial proportion of these two gases. The comparison between the initial gas compositions with the overall value obtained during the first hour of reaction for the concentrations of $\mathrm{H}_{2}$ and $\mathrm{CO}_{2}$ reveals a decrease over time for the former gas together with an increase for the latter due to catalyst deactivation.

The comparison between the proportions of $\mathrm{H}_{2}$ and $\mathrm{CO}_{2}$ in the gas obtained during the APR of cheese whey and lactose reveals a lower initial $\mathrm{H}_{2}$ proportion and a higher initial concentration of $\mathrm{CO}_{2}$ in the gas for the experiments conducted with lactose under the same operating conditions. However, significant variations in the proportions of these two gases for the APR of lactose were not detected. Gas formation takes place via C-C scission, which occurs via a base-catalysed pathway facilitated in the presence of salts $[26,73]$. Therefore, this increase in the proportion of $\mathrm{H}_{2}$ in the gas could be the consequence of the increase in gas production, which also causes a reduction in the production of intermediate liquids. This decreases the $\mathrm{H}_{2}$ consumption in the hydrogenation reactions, which accounts for the lower amount of $\mathrm{H}_{2}$ in the gas obtained from lactose. King et al. [26] also reported an increase in the $\mathrm{H}_{2}$ selectivity with the addition of $\mathrm{KOH}$ during the APR of glycerol using a Pt-Re/C catalyst. They concluded that this development was the consequence of lower $\mathrm{H}_{2}$ consumption in the 
hydrogenation reactions, as $\mathrm{KOH}$ disfavours dehydration reactions and $\mathrm{C}-\mathrm{O}$ scissions.

Conversely, non-significant differences were found for the concentrations of $\mathrm{H}_{2}$ in the gas and their evolution over time between the results obtained in the APR of the real and the filtered cheese whey. This suggests that the elimination of fats and proteins does not significantly influence the gas composition and indicates that the presence of salts in the whey is one of the major factors responsible for the greater concentration of $\mathrm{H}_{2}$ in the gas during the APR of cheese whey. Conversely, the filtration of whey results in an increase in the proportion of $\mathrm{CH}_{4}$ along with a decrease in the relative amount of $\mathrm{CO}_{2}$ in the gas at the beginning of the experiment.

The proportion of $\mathrm{CO}$ in the gas is very low $\left(<2\right.$ vol.\%) regardless of the $\mathrm{W} / \mathrm{m}_{\mathrm{C}}$ ratio and the feedstock (cheese whey, lactose or filtered cheese whey) used in the experiments. Under the temperature studied in this work, the water gas shift (WGS) reaction is shifted towards $\mathrm{H}_{2}$ and $\mathrm{CO}_{2}$, which explains the low proportion of $\mathrm{CO}$ in the gas. In addition, non-statistically significant differences were found between the experiments conducted at different spatial times for the same feedstock or between the different feedstocks.

In contrast, the $\mathrm{W} / \mathrm{m}_{\mathrm{C}}$ ratio exerts a significant influence on the proportion of $\mathrm{CH}_{4}$ in the gas during the APR of cheese whey. The higher the $\mathrm{W} / \mathrm{m}_{\mathrm{C}}$ ratio, the greater the initial proportion of $\mathrm{CH}_{4}$ in the gas and the decay over time observed for this gas. This shifts the process towards the production of liquid end products such as acetaldehyde, which can be converted into $\mathrm{CH}_{4}$ by decarbonylation $[38,42,74]$. The decrease observed in 
the proportion of $\mathrm{CH}_{4}$ might account for a progressive deactivation of the catalyst, which decreases the advancement of the reaction towards final liquid products, thus lowering the amount of $\mathrm{CH}_{4}$ in the gas.

The comparison between the results obtained with cheese whey and lactose does not show significant differences for the concentration of $\mathrm{CH}_{4}$ in the gas. Exceptionally, the decrease over time observed in the proportion of $\mathrm{CH}_{4}$ for the APR of cheese whey when $\mathrm{a} \mathrm{W} / \mathrm{m}_{\mathrm{C}}$ ratio of $95 \mathrm{~g}$ catalyst $\mathrm{min} / \mathrm{g}$ lactose is used does not take place when reforming lactose. This decay over time observed for cheese whey takes place for $\mathrm{W} / \mathrm{m}_{\mathrm{C}}$ ratios between 95 and $130 \mathrm{~g}$ catalyst min/g C. As remarked above, high $\mathrm{W} / \mathrm{m}_{\mathrm{C}}$ promotes a greater shift of cross-linking and polymerisation reactions from furanic compounds whose formation from cheese whey via dehydration is favoured due to the presence of salts. This leads to the formation of substantial quantities of char and coke, causing catalyst deactivation, and could explain the decrease observed in the proportion of this gas during the APR of cheese whey and the steady evolution when using lactose. The filtration of the cheese whey results in a slight increase in the initial proportion of $\mathrm{CH}_{4}$ in the gas.

\subsubsection{Liquid composition}

Fig. 6 summarises the relative amounts of each of the different families of liquid compounds for the different experiments. The liquid phase is made up of a mixture of aldehydes, carboxylic acids, alcohols and ketones in water. Acetaldehyde is the most abundant compound for the aldehydes, while the carboxylic acids are mainly made up of acetic and propionic acids. Alcohols include monohydric alcohols (mainly methanol 
and ethanol), polyhydric alcohols (1,2-propanediol, 1,2-ethanediol, 2,3-butanediol) and, in lower proportions, monohydric substituted (2-methyl-3-pentanol) and alicyclic alcohols (2-furanmethanol). Ketones include C3-ketones such as 2-propanone (acetone) and 2-propanone-1-hydroxy, and C4-ketones (2-butanone-3-hydroxy and 2-butanone-1hydroxy, 2,3-butanedione and 2 butanone). The presence of these compounds in the condensates is consistent with the pathway proposed by several authors studying the APR of polyols and sugar based compounds [26, 27, 35-39, 65-70, 74-83].

The composition of the liquid phase depends on the $\mathrm{W} / \mathrm{m}_{\mathrm{C}}$ ratio and the feedstock. During the APR of cheese whey, an increase in the $\mathrm{W} / \mathrm{m}_{\mathrm{C}}$ ratio from 60 to $95 \mathrm{~g}$ catalyst $\mathrm{min} / \mathrm{g}$ carbon decreases the relative amount of monohydric and polyhydric alcohols and increases the proportion of C3-ketones and carboxylic acids in the liquid, the proportions of C4-ketones and aldehydes being unaffected. In addition, a further increase in the $\mathrm{W} / \mathrm{m}_{\mathrm{C}}$ ratio up to $130 \mathrm{~g}$ catalyst $\mathrm{min} / \mathrm{g}$ carbon leads to an increase in the proportions of alcohols (both monohydric and polyhydric) and carboxylic acids as well as to a decrease in the relative amount of ketones (C3 and $\mathrm{C} 4)$. The initial increase in the $\mathrm{W} / \mathrm{m}_{\mathrm{C}}$ ratio produces a greater spread of chemical reactions in the liquid phase leading to the formation of end liquid products (acetic acid, ethanol, methanol, propan2-ol and propan-1-ol). In addition, this increase in the amount of catalyst enhances monohydric and polyhydric alcohol decomposition to gases when a large amount of catalyst is used [42], thus decreasing their proportions in the liquid. Conversely, a further increase in the $\mathrm{W} / \mathrm{m}_{\mathrm{C}}$ ratio favours the dehydration of glucose and galactose [65$67,69]$. This might hinder the conversion of final liquid products to gas, thus increasing their relative amounts in the liquid. This is in good agreement with the increase observed in the $\mathrm{CC}$ sol and the decrease in the $\mathrm{CC}$ liq. 
Statistically significant differences were found between the chemical compositions of the liquid phase obtained for the APR of cheese whey and lactose, these differences being dependent on the $\mathrm{W} / \mathrm{m}_{\mathrm{C}}$ ratio. For $60 \mathrm{~g}$ catalyst min/g carbon, the liquid phase obtained from cheese whey has greater amounts of alcohols (monohydric and polyhydric) and carboxylic acids and lower proportions of C4-ketones and aldehydes. It is believed that this difference might be the consequence of the lower $\mathrm{CC}$ liq and higher CC sol obtained with cheese whey than with lactose. For $95 \mathrm{~g}$ catalyst $\mathrm{min} / \mathrm{g}$ carbon, higher proportions of C3-ketones and carboxylic acids together with a lower proportion of polyhydric alcohols in the liquid phase are obtained for cheese whey than for lactose. An increase in char formation increases the effective $\mathrm{W} / \mathrm{m}_{\mathrm{C}}$ ratio in the process, thus shifting the composition of the liquid phase towards end products. Very similar liquid compositions were obtained from the real and the filtered cheese whey (non-significant differences are detected for the proportions of ketones, carboxylic acids and aldehydes). Exceptionally, the liquid phase obtained from cheese whey has a greater proportion of monohydric alcohols and a lower amount of polyhydric alcohols.

\subsection{Catalyst deactivation}

Fig. 7 shows the evolution over time of the $\mathrm{CC}$ gas for some steam reforming and aqueous phase reforming experiments. The catalytic steam reforming experiments reveal a decrease in the $\mathrm{CC}$ gas over time for the experiments conducted with lactose due to the progressive deactivation of the catalysts, while an increase in the $\mathrm{CC}$ gas is noticed for the experiments conducted with the cheese whey and filtered cheese whey solutions due to the progressive gasification of the carbon deposits, as commented 
above. A decrease in the $\mathrm{CC}$ gas over time takes place for the aqueous phase reforming experiments.

To gain a better insight into catalyst deactivation, some of the used catalysts were characterised by XRD and elemental analysis. The carbon deposited on the used catalysts was examined and the solid carbon distribution between char and coke was calculated. Table 3 lists the $\mathrm{CC}$ coke, $\mathrm{CC}$ char and the amount of $\mathrm{C}$ deposited on the catalysts during the reforming experiments. The results indicate that the vast majority of the $\mathrm{CC}$ sol is due to the formation of char. Char production is highly likely to occur during the thermal decomposition of lactose. This tendency of sugars to decompose giving char has also been reported for xylose, glucose and sucrose [32, 33]. As regards catalyst deactivation, coking was responsible for the deactivation of the catalysts during the catalytic steam reforming. The amount of $\mathrm{C}$ deposited on the catalysts $(\mathrm{mg} \mathrm{C} / \mathrm{g}$ cat. g organic reacted) is as follows: cheese whey $>$ filtered cheese whey $>$ lactose. This evolution can explain the differences observed during the reforming of the three different liquids. In addition, the lower the temperature, the higher the amount of $\mathrm{C}$ deposited and consequently the deactivation of the catalysts. The amount of $\mathrm{C}$ deposited on the catalyst during the aqueous phase reforming experiment of the three liquids follows the same trend; however, the amount of $\mathrm{C}$ deposited on the surface of the catalysts was much lower.

Fig. 8 shows the XRD patterns of the spent catalysts. The XRD patterns have wide and asymmetric peaks, which denote quite low crystallinity. These analyses indicate the presence of $\mathrm{Ni}, \mathrm{Co}_{3} \mathrm{O}_{4}, \mathrm{NiCo}_{2} \mathrm{O}_{4}, \mathrm{MgO}$ and $\mathrm{MgNiO}_{2}$ in the catalysts used for the catalytic steam reforming experiments, while $\mathrm{Ni}, \mathrm{NiAl}_{2} \mathrm{O}_{3}, \mathrm{LaCO}_{3} \mathrm{OH}$ and boehmite 
$(\mathrm{AlO}(\mathrm{OH}))$ are crystalline phases detected in the catalyst used for the aqueous phase reforming experiments. The nickel crystallite size for the Ni-Co/Al-Mg and Ni/Al-La catalyst was $12.2 \pm 1.5$ and $11.2 \pm 0.66 \mathrm{~nm}$, respectively. This analysis confirms that under the operating conditions of the aqueous phase, the alumina of the support can be transformed into boehmite. This accounts for the deactivation of the catalysts during the aqueous phase reforming [84-86].

\subsection{Comparison between catalytic steam reforming and aqueous phase reforming for} cheese whey management

Table 4 shows a comparison between the overall results obtained during the first hour of reaction in the catalytic steam reforming and aqueous phase reforming of real cheese whey under the best operating conditions tested in this work for each reforming process, to highlight the most important differences between both valorisation routes. To fairly compare both valorisation routes, a steady state comparison would be needed. However, the comparison between the results obtained during the first hour of reaction illustrates the most important differences between the two valorisation routes.

For both processes, a complete lactose conversion is achieved. However, there are significant differences between the carbon converted to gas, liquid and solid products and the composition of the gas and liquid phases. As regards gas production, a higher $\mathrm{CC}$ gas with a greater proportion of $\mathrm{H}_{2}$ is obtained using steam reforming. In addition, a liquid effluent with a negligible amount of $\mathrm{C}$ is obtained, which is beneficial having regard to cheese whey management. In addition, gas production increases over time due to the progressive gasification of the char produced. Therefore, the $\mathrm{CC}$ gas increases 
from 15 to $32 \%$ from the first to the second hour of experiment. Aqueous phase reforming of cheese whey is a more attractive option for the production of valuable liquid products. Around $47 \%$ of the carbon content of the feed is transformed into a mixture of alcohols, ketones, carboxylic acids and aldehydes.

Solid carbon conversion is the major drawback for both processes; $85 \%$ and $46 \%$ of the carbon content of the feed is converted into char during the steam reforming and aqueous phase reforming of cheese whey, respectively. This high degree of solid formation causes operational problems for both valorisation routes. Having regard to the evolution of the $\mathrm{CC}$ gas and $\mathrm{CC}$ sol over time, a fluidised bed reactor could be the most appropriate option for $\mathrm{H}_{2}$ production from cheese whey by catalytic steam reforming. This reactor configuration allows an easier gasification of the char to take place, which may result in greater $\mathrm{H}_{2}$ production. In previous works using crude glycerol $[87,88]$, it was found that this reactor configuration can overcome the substantial formation of char from organic feedstocks with a high proportion of salts. In addition, gas production increases over time due to the positive catalytic effect of salts in the gasification of carbon deposits, a development which is intensified in this type of contactor. As regards the energetic issues of this process, in a previous work an energetic assessment was conducted using lactose [31]. It was found that the combustion of part of the reforming gas produced could provide the energy necessary for the process. This combined process (reforming and combustion of part of the gas) produces a rich $\mathrm{H}_{2}$ gas from lactose when a high $\mathrm{CC}$ gas $(>80 \%)$ is achieved in the reforming process. Therefore, further research is still necessary with cheese whey to reduce solid formation. 
Solid formation represents a serious drawback for aqueous phase reforming due to the blockage of the micrometric valve that controls the pressure in the experimental rig used in this work. One possible solution could be the use of a batch reactor; another might be a modification of the experimental installation. For this modification, the condensers could be placed before the micrometric valve to separate char and solid from the gas mixture before they reach the valve. This would involve the use of pressurised vessels for the condensation unit. Finally, after overcoming the high char formation during the reforming of whey, future research should focus on catalyst development and regeneration.

\section{Conclusions}

This work addresses the valorisation of cheese whey by catalytic steam reforming and aqueous phase reforming (APR). Both processes have been experimentally evaluated using a Ni-based catalyst. In addition, the results obtained with cheese whey have been compared to those using filtered cheese whey and a lactose solution, the major organic constituent of this wastewater. The most important conclusions obtained from this work are summarised as follows.

1. Catalytic steam reforming is a promising process for cheese whey management. It enables the organic compounds present in the cheese whey to be transformed into a rich $\mathrm{H}_{2}$ gas (up to $30 \% \mathrm{CC}$ gas in $2 \mathrm{~h}$, with a concentration of $\mathrm{H}_{2}$ of 70 vol.\%) reducing the amount of carbon present in the liquid effluent, which results in an almost carbon-free liquid stream $(\mathrm{CC}$ liq $<1 \%)$.

2. Aqueous phase reforming is a potential process for the production of valuable liquids from cheese whey. The CC gas obtained during the aqueous phase reforming of cheese whey is relatively low. In contrast, relatively high CC liq (47\%) can be achieved from 
cheese whey by aqueous phase reforming. This liquid phase is made up of a mixture of aldehydes, carboxylic acids, alcohols and ketones in water. The chemical composition of this liquid phase is dependent on the amount of catalyst used.

3. The formation of char is the major drawback for the correct development of catalytic steam reforming and aqueous phase reforming. This char formation is enhanced by the presence of salts in cheese whey. This substantial solid formation (CC sol $>45 \%)$ hampers higher $\mathrm{CC}$ gas and $\mathrm{CC}$ liq from being achieved from cheese whey by steam reforming and aqueous phase reforming, respectively. New reactor configurations and/or the elimination of salts from the feedstock might overcome this problem.

4. Filtration of the cheese whey slightly reduces the formation of char. However, this filtration only marginally changes the composition of the gas for steam reforming or the liquid phase for aqueous reforming compared to the results obtained with real cheese whey.

\section{Acknowledgements}

The authors wish to express their gratitude to the Aragon Government and the European Social Fund (GPT group) and the Spanish MINECO (projects ENE2010-18985 and ENE2013-41523-R) for providing financial support. The authors would also like to acknowledge the use of the Servicio General de Apoyo a la Investigación-SAI of the Universidad de Zaragoza. Furthermore, we would like to thanks "Quesos La Pardina” for having provided the cheese whey used in this work. In addition, Javier Remón Núñez would like to express his gratitude to the Spanish MINECO for the FPI grant awarded (BES- 2011-044856). 


\section{References}

[1] F. Carvalho, A.R. Prazeres, J. Rivas, Cheese whey wastewater: characterization and treatment, The Science of the Total Environment, 445-446 (2013) 385-396.

[2] R.R. de Souza, R. Bergamasco, S.C. da Costa, X. Feng, S.H.B. Faria, M.L. Gimenes, Recovery and purification of lactose from whey, Chemical Engineering and Processing: Process Intensification, 49 (2010) 1137-1143.

[3] A.R. Prazeres, F. Carvalho, J. Rivas, Cheese whey management: a review, Journal of Environmental Management, 110 (2012) 48-68.

[4] M.I.G. Siso, The biotechnological utilization of cheese whey: A review, Bioresource Technology, 57 (1996) 1-11.

[5] O. Díaz, C.D. Pereira, A. Cobos, Functional properties of ovine whey protein concentrates produced by membrane technology after clarification of cheese manufacture by-products, Food Hydrocolloids, 18 (2004) 601-610.

[6] D. Mišún, L. Čurda, P. Jelen, Batch and continuous hydrolysis of ovine whey proteins, Small Ruminant Research, 79 (2008) 51-56.

[7] G. Guven, A. Perendeci, A. Tanyolac, Electrochemical treatment of deproteinated whey wastewater and optimization of treatment conditions with response surface methodology, Journal of Hazardous Materials, 157 (2008) 69-78.

[8] S. Ozmihci, F. Kargi, Ethanol production from cheese whey powder solution in a packed column bioreactor at different hydraulic residence times, Biochemical Engineering Journal, 42 (2008) 180-185.

[9] G. Vidal, A. Carvalho, R. Méndez, J.M. Lema, Influence of the content in fats and proteins on the anaerobic biodegradability of dairy wastewaters, Bioresource Technology, 74 (2000) 231-239.

[10] A.J. Mawson, Bioconversions for whey utilization and waste abatement, Bioresource Technology, 47 (1994) 195-203.

[11] S. Sansonetti, S. Curcio, V. Calabrò, G. Iorio, Bio-ethanol production by fermentation of ricotta cheese whey as an effective alternative non-vegetable source, Biomass and Bioenergy, 33 (2009) 1687-1692.

[12] J.J. Fitzpatrick, C. Murphy, F.M. Mota, T. Pauli, Impurity and cost considerations for nutrient supplementation of whey permeate fermentations to produce lactic acid for biodegradable plastics, International Dairy Journal, 13 (2003) 575-580.

[13] M.I. González, S. Álvarez, F. Riera, R. Álvarez, Economic evaluation of an integrated process for lactic acid production from ultrafiltered whey, Journal of Food Engineering, 80 (2007) 553-561.

[14] U. Kulozik, J. Wilde, Rapid lactic acid production at high cell concentrations in whey ultrafiltrate by Lactobacillus helveticus, Enzyme and Microbial Technology, 24 (1999) 297-302.

[15] A.W. Schepers, J. Thibault, C. Lacroix, Continuous lactic acid production in whey permeate/yeast extract medium with immobilized Lactobacillus helveticus in a twostage process: Model and experiments, Enzyme and Microbial Technology, 38 (2006) 324-337.

[16] A. Vasala, J. Panula, P. Neubauer, Efficient lactic acid production from high salt containing dairy by-products by Lactobacillus salivarius ssp. salicinius with pretreatment by proteolytic microorganisms, Journal of Biotechnology, 117 (2005) 421431. 
[17] M. Ferchichi, E. Crabbe, G.-H. Gil, W. Hintz, A. Almadidy, Influence of initial pH on hydrogen production from cheese whey, Journal of Biotechnology, 120 (2005) 402409.

[18] L.M. Rosales-Colunga, E. Razo-Flores, L.G. Ordoñez, F. Alatriste-Mondragón, A. De León-Rodríguez, Hydrogen production by Escherichia coli Ahyca Alaci using cheese whey as substrate, International Journal of Hydrogen Energy, 35 (2010) 491499.

[19] N. Azbar, F.T. Cetinkaya Dokgoz, The effect of dilution and 1-malic acid addition on bio-hydrogen production with Rhodopseudomonas palustris from effluent of an acidogenic anaerobic reactor, International Journal of Hydrogen Energy, 35 (2010) 5028-5033.

[20] N. Azbar, F.T. Çetinkaya Dokgöz, T. Keskin, K.S. Korkmaz, H.M. Syed, Continuous fermentative hydrogen production from cheese whey wastewater under thermophilic anaerobic conditions, International Journal of Hydrogen Energy, 34 (2009) 7441-7447.

[21] N. Venetsaneas, G. Antonopoulou, K. Stamatelatou, M. Kornaros, G. Lyberatos, Using cheese whey for hydrogen and methane generation in a two-stage continuous process with alternative $\mathrm{pH}$ controlling approaches, Bioresource Technology, 100 (2009) 3713-3717.

[22] P. Yang, R. Zhang, J. McGarvey, J. Benemann, Biohydrogen production from cheese processing wastewater by anaerobic fermentation using mixed microbial communities, International Journal of Hydrogen Energy, 32 (2007) 4761-4771.

[23] M. Shukla, Y.K. Jha, S. Admassu, Development of Probiotic Beverage from Whey and Pineapple Juice, Journal of Food Processing and Technology, 04 (2013) 206-209.

[24] K. Prendergast, Whey drinks - technology, processing and marketing, International Journal of Dairy Technology, 38 (1985) 103-105.

[25] X. Song, Z. Guo, Technologies for direct production of flexible $\mathrm{H}_{2} / \mathrm{CO}$ synthesis gas, Energy Conversion and Management, 47 (2006) 560-569.

[26] D.L. King, L. Zhang, G. Xia, A.M. Karim, D.J. Heldebrant, X. Wang, T. Peterson, Y. Wang, Aqueous phase reforming of glycerol for hydrogen production over Pt-Re supported on carbon, Applied Catalysis B: Environmental, 99 (2010) 206-213.

[27] Y.-C. Lin, Catalytic valorization of glycerol to hydrogen and syngas, International Journal of Hydrogen Energy, 38 (2013) 2678-2700.

[28] M. Metsoviti, K. Paraskevaidi, A. Koutinas, A.-P. Zeng, S. Papanikolaou, Production of 1,3-propanediol, 2,3-butanediol and ethanol by a newly isolated Klebsiella oxytoca strain growing on biodiesel-derived glycerol based media, Process Biochemistry, 47 (2012) 1872-1882.

[29] Z. Yuan, J. Wang, L. Wang, W. Xie, P. Chen, Z. Hou, X. Zheng, Biodiesel derived glycerol hydrogenolysis to 1,2-propanediol on $\mathrm{Cu} / \mathrm{MgO}$ catalysts, Bioresource Technology, 101 (2010) 7099-7103.

[30] J.W. Shabaker, G.W. Huber, J.A. Dumesic, Aqueous-phase reforming of oxygenated hydrocarbons over Sn-modified Ni catalysts, Journal of Catalysis, 222 (2004) 180-191.

[31] J. Remón, M. Laseca, L. García, J. Arauzo, Hydrogen production from cheese whey by catalytic steam reforming: Preliminary study using lactose as a model compound, Energy Conversion and Management, 114 (2016) 122-141.

[32] X. Hu, G. Lu, Investigation of the steam reforming of a series of model compounds derived from bio-oil for hydrogen production, Applied Catalysis B: Environmental, 88 (2009) 376-385. 
[33] M. Marquevich, S. Czernik, E. Chornet, D. Montané, Hydrogen from Biomass: Steam Reforming of Model Compounds of Fast-Pyrolysis Oil, Energy and Fuels, 13 (1999) 1160-1166.

[34] S. Tosti, M. Zerbo, A. Basile, V. Calabrò, F. Borgognoni, A. Santucci, Pd-based membrane reactors for producing ultra pure hydrogen: Oxidative reforming of bioethanol, International Journal of Hydrogen Energy, 38 (2013) 701-707.

[35] T. Jiang, T. Wang, L. Ma, Y. Li, Q. Zhang, X. Zhang, Investigation on the xylitol aqueous-phase reforming performance for pentane production over Pt/HZSM-5 and Ni/HZSM-5 catalysts, Applied Energy, 90 (2012) 51-57.

[36] A.V. Kirilin, A.V. Tokarev, H. Manyar, C. Hardacre, T. Salmi, J.P. Mikkola, D.Y. Murzin, Aqueous phase reforming of xylitol over Pt-Re bimetallic catalyst: Effect of the Re addition, Catalysis Today, 223 (2014) 97-107.

[37] J. Xi, Q. Xia, Y. Shao, D. Ding, P. Yang, X. Liu, G. Lu, Y. Wang, Production of hexane from sorbitol in aqueous medium over $\mathrm{Pt} / \mathrm{NbOPO}_{4}$ catalyst, Applied Catalysis B: Environmental, 181 (2016) 699-706.

[38] F. Aiouache, L. McAleer, Q. Gan, A.a.H. Al-Muhtaseb, M.N. Ahmad, Path lumping kinetic model for aqueous phase reforming of sorbitol, Applied Catalysis A: General, 466 (2013) 240-255.

[39] A.V. Kirilin, A.V. Tokarev, L.M. Kustov, T. Salmi, J.P. Mikkola, D.Y. Murzin, Aqueous phase reforming of xylitol and sorbitol: Comparison and influence of substrate structure, Applied Catalysis A: General, 435-436 (2012) 172-180.

[40] L.I. Godina, A.V. Kirilin, A.V. Tokarev, D.Y. Murzin, Aqueous Phase Reforming of Industrially Relevant Sugar Alcohols with Different Chiralities, ACS Catalysis, 5 (2015) 2989-3005.

[41] J. Remón, J.A. Medrano, F. Bimbela, L. García, J. Arauzo, Ni/Al-Mg-O solids modified with $\mathrm{Co}$ or $\mathrm{Cu}$ for the catalytic steam reforming of bio-oil, Applied Catalysis B: Environmental, 132-133 (2013) 433-444.

[42] J. Remón, J.R. Giménez, A. Valiente, L. García, J. Arauzo, Production of gaseous and liquid chemicals by aqueous phase reforming of crude glycerol: Influence of operating conditions on the process, Energy Conversion and Management, 110 (2016) 90-112.

[43] J. Remón, F. Broust, J. Valette, Y. Chhiti, I. Alava, A.R. Fernandez-Akarregi, J. Arauzo, L. Garcia, Production of a hydrogen-rich gas from fast pyrolysis bio-oils: Comparison between homogeneous and catalytic steam reforming routes, International Journal of Hydrogen Energy, 39 (2014) 171-182.

[44] J. Remón, F. Broust, G. Volle, L. García, J. Arauzo, Hydrogen production from pine and poplar bio-oils by catalytic steam reforming. Influence of the bio-oil composition on the process, International Journal of Hydrogen Energy, 40 (2015) 55935608 .

[45] A. Valiente, J.A. Medrano, M. Oliva, J. Ruiz, L. Garcia, J. Arauzo, Bioenergy II: Hydrogen Production by Aqueous-Phase Reforming, International Journal of Chemical Reactor Engineering, 8 (2010).

[46] R.R. Davda, J.W. Shabaker, G.W. Huber, R.D. Cortright, J.A. Dumesic, A review of catalytic issues and process conditions for renewable hydrogen and alkanes by aqueous-phase reforming of oxygenated hydrocarbons over supported metal catalysts, Applied Catalysis B: Environmental, 56 (2005) 171-186.

[47] Z. Abu El-Rub, E.A. Bramer, G. Brem, Experimental comparison of biomass chars with other catalysts for tar reduction, Fuel, 87 (2008) 2243-2252. 
[48] N.B. Klinghoffer, M.J. Castaldi, A. Nzihou, Influence of char composition and inorganics on catalytic activity of char from biomass gasification, Fuel, 157 (2015) 3747.

[49] Z. Min, P. Yimsiri, M. Asadullah, S. Zhang, C.-Z. Li, Catalytic reforming of tar during gasification. Part II. Char as a catalyst or as a catalyst support for tar reforming, Fuel, 90 (2011) 2545-2552.

[50] T.Y. Mun, J.O. Kim, J.W. Kim, J.S. Kim, Influence of operation conditions and additives on the development of producer gas and tar reduction in air gasification of construction woody wastes using a two-stage gasifier, Bioresource Technology, 102 (2011) 7196-7203.

[51] T. Oike, S. Kudo, H. Yang, J. Tahara, H.-S. Kim, R. Koto, K. Norinaga, J.-i. Hayashi, Sequential Pyrolysis and Potassium-Catalyzed Steam-Oxygen Gasification of Woody Biomass in a Continuous Two-Stage Reactor, Energy and Fuels, 28 (2014) 6407-6418.

[52] N. Striūgas, K. Zakarauskas, G. Stravinskas, V. Grigaitienè, Comparison of steam reforming and partial oxidation of biomass pyrolysis tars over activated carbon derived from waste tire, Catalysis Today, 196 (2012) 67-74.

[53] D. Wang, W. Yuan, W. Ji, Char and char-supported nickel catalysts for secondary syngas cleanup and conditioning, Applied Energy, 88 (2011) 1656-1663.

[54] A.A. Zardini, I. Riipinen, I.K. Koponen, M. Kulmala, M. Bilde, Evaporation of ternary inorganic/organic aqueous droplets: Sodium chloride, succinic acid and water, Journal of Aerosol Science, 41 (2010) 760-770.

[55] R.P.B. Ramachandran, G. van Rossum, W.P.M. van Swaaij, S.R.A. Kersten, Evaporation of Biomass Fast Pyrolysis Oil: Evaluation of char formation, Environmental Progress \& Sustainable Energy, 28 (2009) 410-417.

[56] C. Font Palma, A.D. Martin, Inorganic constituents formed during small-scale gasification of poultry litter: A model based study, Fuel Processing Technology, 116 (2013) 300-307.

[57] P. Nanou, H.E. Gutiérrez Murillo, W.P.M. van Swaaij, G. van Rossum, S.R.A. Kersten, Intrinsic reactivity of biomass-derived char under steam gasification conditions-potential of wood ash as catalyst, Chemical Engineering Journal, 217 (2013) 289-299.

[58] S. Czernik, R. French, C. Feik, E. Chornet, Hydrogen by catalytic steam reforming of liquid byproducts from biomass thermoconversion processes. Fuel and Energy Abstracts, 44 (2003) 232.

[59] M. Bertero, G. de la Puente, U. Sedran, Fuels from bio-oils: Bio-oil production from different residual sources, characterization and thermal conditioning, Fuel, 95 (2012) 263-271.

[60] M. Bertero, U. Sedran, Conversion of pine sawdust bio-oil (raw and thermally processed) over equilibrium FCC catalysts, Bioresource Technology, 135 (2013) 644651.

[61] Y. Wang, X. Hu, D. Mourant, Y. Song, L. Zhang, C. Lievens, J. Xiang, C.-Z. Li, Evolution of aromatic structures during the reforming of bio-oil: Importance of the interactions among bio-oil components, Fuel, 111 (2013) 805-812.

[62] Y. Wang, D. Mourant, X. Hu, S. Zhang, C. Lievens, C.-Z. Li, Formation of coke during the pyrolysis of bio-oil, Fuel, 108 (2013) 439-444.

[63] C.A. Fisk, T. Morgan, Y. Ji, M. Crocker, C. Crofcheck, S.A. Lewis, Bio-oil upgrading over platinum catalysts using in situ generated hydrogen, Applied Catalysis A: General, 358 (2009) 150-156. 
[64] T. Jiang, Q. Zhang, T.-J. Wang, Q. Zhang, L.-L. Ma, High yield of pentane production by aqueous-phase reforming of xylitol over Ni/HZSM-5 and Ni/MCM22 catalysts, Energy Conversion and Management, 59 (2012) 58-65.

[65] J.N. Chheda, J.A. Dumesic, An overview of dehydration, aldol-condensation and hydrogenation processes for production of liquid alkanes from biomass-derived carbohydrates, Catalysis Today, 123 (2007) 59-70.

[66] G.W. Huber, J.A. Dumesic, An overview of aqueous-phase catalytic processes for production of hydrogen and alkanes in a biorefinery, Catalysis Today, 111 (2006) 119132.

[67] D.W. Rackemann, J.P. Bartley, W.O.S. Doherty, Methanesulfonic acid-catalyzed conversion of glucose and xylose mixtures to levulinic acid and furfural, Industrial Crops and Products, 52 (2014) 46-57.

[68] M.J. Taylor, L.J. Durndell, M.A. Isaacs, C.M.A. Parlett, K. Wilson, A.F. Lee, G. Kyriakou, Highly selective hydrogenation of furfural over supported Pt nanoparticles under mild conditions, Applied Catalysis B: Environmental, 180 (2016) 580-585. [69] J. Tuteja, S. Nishimura, K. Ebitani, One-Pot Synthesis of Furans from Various Saccharides Using a Combination of Solid Acid and Base Catalysts, Bulletin of the Chemical Society of Japan, 85 (2012) 275-281.

[70] K. Yan, G. Wu, T. Lafleur, C. Jarvis, Production, properties and catalytic hydrogenation of furfural to fuel additives and value-added chemicals, Renewable and Sustainable Energy Reviews, 38 (2014) 663-676.

[71] H. Atia, U. Armbruster, A. Martin, Influence of alkaline metal on performance of supported silicotungstic acid catalysts in glycerol dehydration towards acrolein, Applied Catalysis A: General, 393 (2011) 331-339.

[72] J. Haber, K. Pamin, L. Matachowski, B. Napruszewska, J. Połtowicz, Potassium and silver salts of tungstophosphoric acid as catalysts in dehydration of ethanol and hydration of ethylene, Journal of Catalysis, 207 (2002) 296-306.

[73] D.G. Lahr, B.H. Shanks, Kinetic Analysis of the Hydrogenolysis of Lower Polyhydric Alcohols: Glycerol to Glycols, Industrial and Engineering Chemistry Research, 42 (2003) 5467-5472.

[74] A. Wawrzetz, B. Peng, A. Hrabar, A. Jentys, A.A. Lemonidou, J.A. Lercher, Towards understanding the bifunctional hydrodeoxygenation and aqueous phase reforming of glycerol, Journal of Catalysis, 269 (2010) 411-420.

[75] S.N. Delgado, D. Yap, L. Vivier, C. Especel, Influence of the nature of the support on the catalytic properties of Pt-based catalysts for hydrogenolysis of glycerol, Journal of Molecular Catalysis A: Chemical, 367 (2013) 89-98.

[76] I. Gandarias, P.L. Arias, J. Requies, M.B. Güemez, J.L.G. Fierro, Hydrogenolysis of glycerol to propanediols over a Pt/ASA catalyst: The role of acid and metal sites on product selectivity and the reaction mechanism, Applied Catalysis B: Environmental, 97 (2010) 248-256.

[77] J. Lee, Y. Xu, G.W. Huber, High-throughput screening of monometallic catalysts for aqueous-phase hydrogenation of biomass-derived oxygenates, Applied Catalysis B: Environmental, 140-141 (2013) 98-107.

[78] G. Liang, L. He, H. Cheng, W. Li, X. Li, C. Zhang, Y. Yu, F. Zhao, The hydrogenation/dehydrogenation activity of supported Ni catalysts and their effect on hexitols selectivity in hydrolytic hydrogenation of cellulose, Journal of Catalysis, 309 (2014) 468-476.

[79] C. Liu, C. Zhang, S. Hao, S. Sun, K. Liu, J. Xu, Y. Zhu, Y. Li, WOx modified $\mathrm{Cu} / \mathrm{Al}_{2} \mathrm{O}_{3}$ as a high-performance catalyst for the hydrogenolysis of glucose to 1,2propanediol, Catalysis Today, 261 (2016) 116-127. 
[80] D. Roy, B. Subramaniam, R.V. Chaudhari, Aqueous phase hydrogenolysis of glycerol to 1,2-propanediol without external hydrogen addition, Catalysis Today, 156 (2010) 31-37.

[81] S.P. Verevkin, V.N. Emel'yanenko, E.N. Stepurko, R.V. Ralys, D.H. Zaitsau, A. Stark, Biomass-Derived Platform Chemicals: Thermodynamic Studies on the Conversion of 5-Hydroxymethylfurfural into Bulk Intermediates, Industrial \& Engineering Chemistry Research, 48 (2009) 10087-10093.

[82] Z. Xinghua, W. Tiejun, M. Longlong, W. Chuangzhi, Aqueous-phase catalytic process for production of pentane from furfural over nickel-based catalysts, Fuel, 89 (2010) 2697-2702.

[83] L. Zhang, A.M. Karim, M.H. Engelhard, Z. Wei, D.L. King, Y. Wang, Correlation of $\mathrm{Pt}-\mathrm{Re}$ surface properties with reaction pathways for the aqueous-phase reforming of glycerol, Journal of Catalysis, 287 (2012) 37-43.

[84] N. Luo, X. Fu, F. Cao, T. Xiao, P.P. Edwards, Glycerol aqueous phase reforming for hydrogen generation over Pt catalyst - Effect of catalyst composition and reaction conditions, Fuel, 87 (2008) 3483-3489.

[85] G. Wen, Y. Xu, H. Ma, Z. Xu, Z. Tian, Production of hydrogen by aqueous-phase reforming of glycerol, Int. J. Hydrog. Energy, 33 (2008) 6657-6666.

[86] M. El Doukkali, A. Iriondo, J.F. Cambra, I. Gandarias, L. Jalowiecki-Duhamel, F. Dumeignil, P.L. Arias, Deactivation study of the Pt and/or Ni-based $\gamma-\mathrm{Al}_{2} \mathrm{O}_{3}$ catalysts used in the aqueous phase reforming of glycerol for $\mathrm{H}_{2}$ production, Applied Catalysis A: General, 472 (2014) 80-91.

[87] J. Remón, C. Jarauta-Córdoba, L. García, J. Arauzo, Analysis and optimisation of $\mathrm{H} 2$ production from crude glycerol by steam reforming using a novel two step process, Fuel Processing Technology, 145 (2016) 130-147.

[88] J. Remón, V. Mercado, L. García, J. Arauzo, Effect of acetic acid, methanol and potassium hydroxide on the catalytic steam reforming of glycerol: Thermodynamic and experimental study, Fuel Processing Technology, 138 (2015) 325-336. 


\section{TABLES}

Table 1. Cheese whey properties. Results are presented as mean \pm standard deviation.

\begin{tabular}{lll}
\hline Composition & Cheese whey & Filtered cheese whey \\
Organic compounds (wt.\%) & $10.49 \pm 0.22$ & $10.08 \pm 0.25$ \\
Lactose (wt.\%) & $4.71 \pm 0.11$ & $5.44 \pm 0.13$ \\
Acetic acid (wt.\%) & $1.37 \pm 0.04$ & $1.58 \pm 0.04$ \\
Formic acid (wt.\%) & $0.68 \pm 0.02$ & $0.79 \pm 0.02$ \\
Sorbic acid (wt.\%) & $1.81 \pm 0.02$ & $0.93 \pm 0.03$ \\
2-propanamine (wt.\%) & $1.17 \pm 0.03$ & $0.02 \pm 0.03$ \\
$\mathrm{H}_{2} \mathrm{O}$ (wt.\%) & $90.74 \pm 1.08$ & $89.38 \pm 1.28$ \\
Ashes (wt.\%) & $0.522 \pm 0.0004$ & $0.542 \pm 0.0004$ \\
\hline Ultimate Analysis & & \\
$\mathrm{C}$ (wt.\%) & $2.73 \pm 0.04$ & $2.15 \pm 0.04$ \\
$\mathrm{H}$ (wt.\%) & $8.97 \pm 0.18$ & $9.05 \pm 0.16$ \\
O (wt.\%) & $87.94 \pm 0.23$ & $88.76 \pm 0.18$ \\
$\mathrm{~N}$ (wt.\%) & $0.36 \pm 0.13$ & $0.06 \pm 0.13$ \\
TOC (ppm) & $29337 \pm 512$ & $24970 \pm 432$ \\
\hline Physical properties & & \\
pH & $7.13 \pm 0.02$ & $7.10 \pm 0.05$ \\
Density (g/mL) & $1.010 \pm 0.001$ & $1.010 \pm 0.001$ \\
\hline${ }^{a}$ Determined by difference & &
\end{tabular}

${ }^{a}$ Determined by difference 
Table 2. Response variables. Definitions and analytical techniques used in their determination.

\begin{tabular}{|c|c|c|}
\hline Product & Response variable & Analytical method \\
\hline Gas & $\begin{array}{c}\text { CC gas }(\%)=\frac{\text { C in the gas }(\mathrm{g})}{\mathrm{C} \text { fed }(\mathrm{g})} 100 \\
\text { Composition (vol. \%) }=\frac{\text { mol of each gas }}{\text { total mol of gas }} 100\end{array}$ & $\begin{array}{c}\text { Micro Gas Chromatograph (Micro GC). } \mathrm{N}_{2} \text { as } \\
\text { internal standard } \\
\text { Online analyses }\end{array}$ \\
\hline Liquid & $\begin{array}{c}\text { CC liq }(\%)=\frac{\text { C in the liquid products }(\mathrm{g})}{\mathrm{C} \text { fed }(\mathrm{g})} 100 \\
\text { Composition (area \%) }=\frac{\text { area of each compound }}{\text { total area }} 100 \\
\text { X lactose }(\%)=\frac{\text { lactose fed }(\mathrm{g})-\text { lactose in the liquid }(\mathrm{g})}{\text { lactose fed }(\mathrm{g})} 100\end{array}$ & $\begin{array}{l}\text { Total Organic Carbon (TOC). } \\
\text { GC-MS (Gas Chromatography-Mass Spectrometry) } \\
\text { HPLC (High Performance Liquid Chromatography) } \\
\text { Offline analyses }\end{array}$ \\
\hline Solid & CC sol $(\%)=100-$ CC gas (\%) - CC liq ${ }^{*}(\%)$ & \\
\hline
\end{tabular}

CC liq $=$ Carbon conversion to liquid products (unreacted lactose free).

CC $\operatorname{liq}^{*}=$ Carbon conversion to liquids including unreacted lactose

Table 3. Solid carbon distribution. Overall carbon conversion to solid, char and coke and $C$ deposited on the catalyst.

\begin{tabular}{|c|c|c|c|c|}
\hline Run & CC solid (\%) & CC char $(\%)$ & CC coke $(\%)$ & C (mg C/g cat. g org.) \\
\hline SR-CW- $450^{\circ} \mathrm{C}-\mathrm{W} / \mathrm{m}=24$ & $78.4 \pm 1.7$ & $76.0 \pm 1.6$ & $2.43 \pm 0.04$ & $404 \pm 20$ \\
\hline SR-FCW- $450^{\circ} \mathrm{C}-\mathrm{W} / \mathrm{m}=24$ & 74.3 & 71.2 & 3.1 & 367 \\
\hline SR-Lactose- $450^{\circ} \mathrm{C}-\mathrm{W} / \mathrm{m}=24$ & $25.1 \pm 0.98$ & $24.5 \pm 0.72$ & $0.51 \pm 0.12$ & $0.84 \pm 0.08$ \\
\hline SR-CW- $600^{\circ} \mathrm{C}-\mathrm{W} / \mathrm{m}=24$ & 74.2 & 71.5 & 2.82 & 333 \\
\hline SR-FCW- $600^{\circ} \mathrm{C}-\mathrm{W} / \mathrm{m}=24$ & 67 & 63.9 & 3.1 & 280 \\
\hline SR-Lactose $-600^{\circ} \mathrm{C}-\mathrm{W} / \mathrm{m}=24$ & 30.0 & 25.87 & 4.13 & 0.58 \\
\hline APR-CW- $450^{\circ} \mathrm{C}-\mathrm{W} / \mathrm{m}=95$ & $46.4 \pm 2.2$ & $45.8 \pm 2.1$ & $0.61 \pm 0.06$ & $28 \pm 1.1$ \\
\hline APR-FCW- $450^{\circ} \mathrm{C}-\mathrm{W} / \mathrm{m}=95$ & 40.3 & 39.9 & 0.45 & 20 \\
\hline APR-Lactose $-450^{\circ} \mathrm{C}-\mathrm{W} / \mathrm{m}=95$ & 1.02 & 0.64 & 0.38 & 12 \\
\hline
\end{tabular}


Table 4. Comparison between catalytic steam reforming and aqueous phase reforming for the first hour of experiment. Results are presented as mean $\pm 0.5 \mathrm{LSD}$

\begin{tabular}{lll}
\hline & Steam Reforming & Aqueous Phase reforming \\
\hline Operating conditions & & \\
$\mathrm{T}\left({ }^{\circ} \mathrm{C}\right)$ & 600 & 220 \\
$\mathrm{P}($ bar) & 1 & 44 \\
$\mathrm{~W} / \mathrm{m}_{\mathrm{C}}$ (g cat min/g C) & 38 & 95 \\
\hline Global results & \\
$\mathrm{X}$ lactose (\%) & 100 & 100 \\
$\mathrm{CC}$ gas (\%) & $14.84 \pm 2.21$ & $6.46 \pm 1.69$ \\
$\mathrm{CC}$ liq (\%) & $0.1 \pm 3.60$ & $47.11 \pm 2.82$ \\
$\mathrm{CC}$ sol (\%) & $85.06 \pm 2.55$ & $46.42 \pm 2.99$ \\
\hline Gas phase composition & & \\
$\mathrm{H}_{2}$ (vol.\%) & $67.23 \pm 1.60$ & $32.58 \pm 3.00$ \\
$\mathrm{CO}$ (vol.\%) & $31.96 \pm 1.60$ & $54.9 \pm 3.00$ \\
$\mathrm{CO}$ (vol.\%) & $0.26 \pm 1.10$ & $0.63 \pm 0.68$ \\
$\mathrm{CH}{ }_{4}$ (vol.\%) & $0.54 \pm 0.12$ & $10.30 \pm 1.25$ \\
\hline Liquid Composition (\% Area) & & \\
Alcohols & 0 & $49.83 \pm 6.45$ \\
Ketones & 0 & $38.88 \pm 3.90$ \\
Carboxylic acids & 0 & $16.11 \pm 1.15$ \\
Aldehydes & 0 & $1.02 \pm 0.32$ \\
\hline
\end{tabular}




\section{FIGURES}

a)

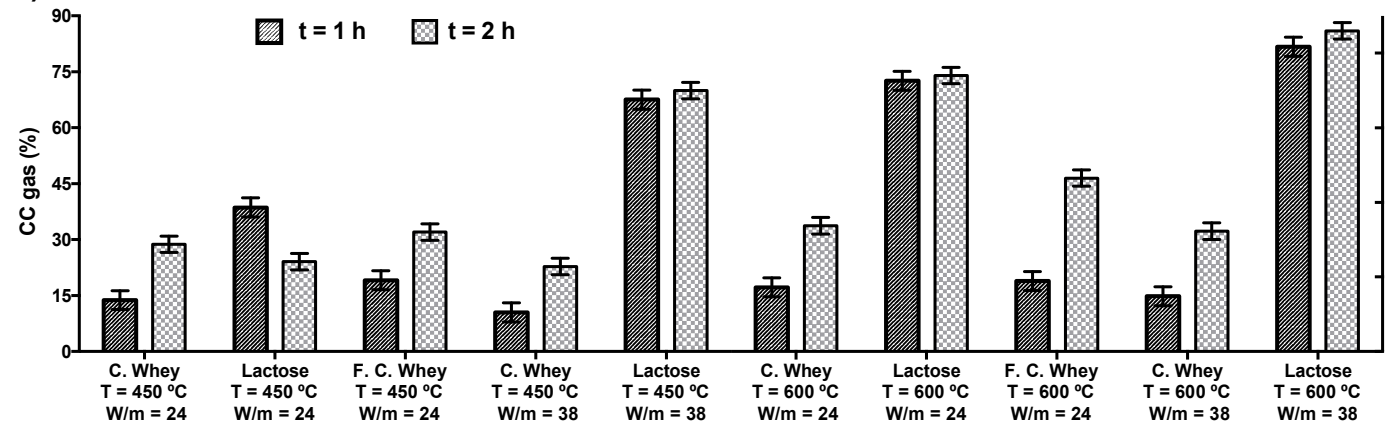

b)

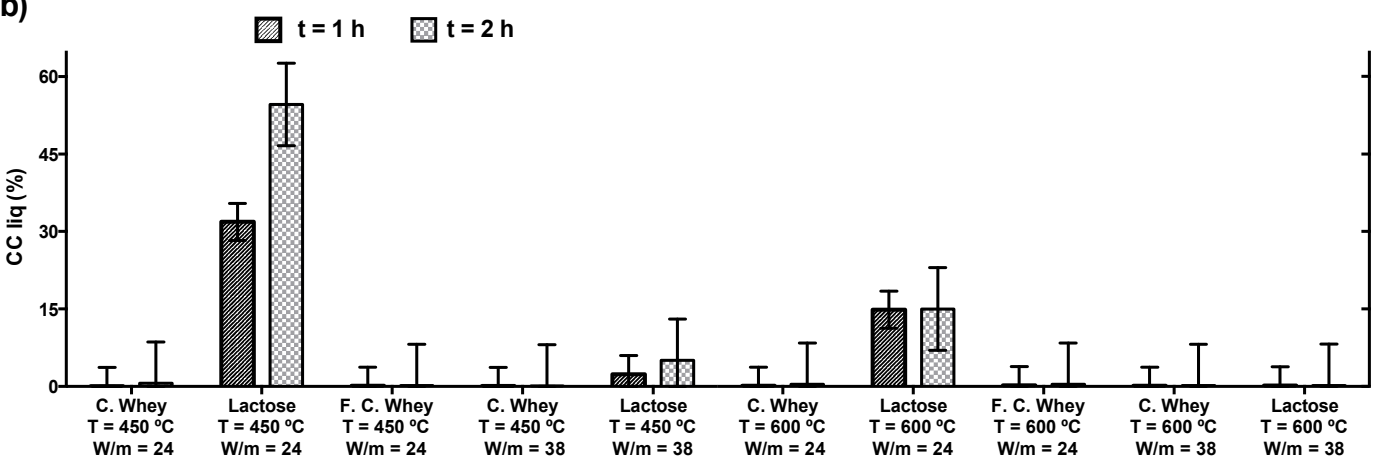

c)

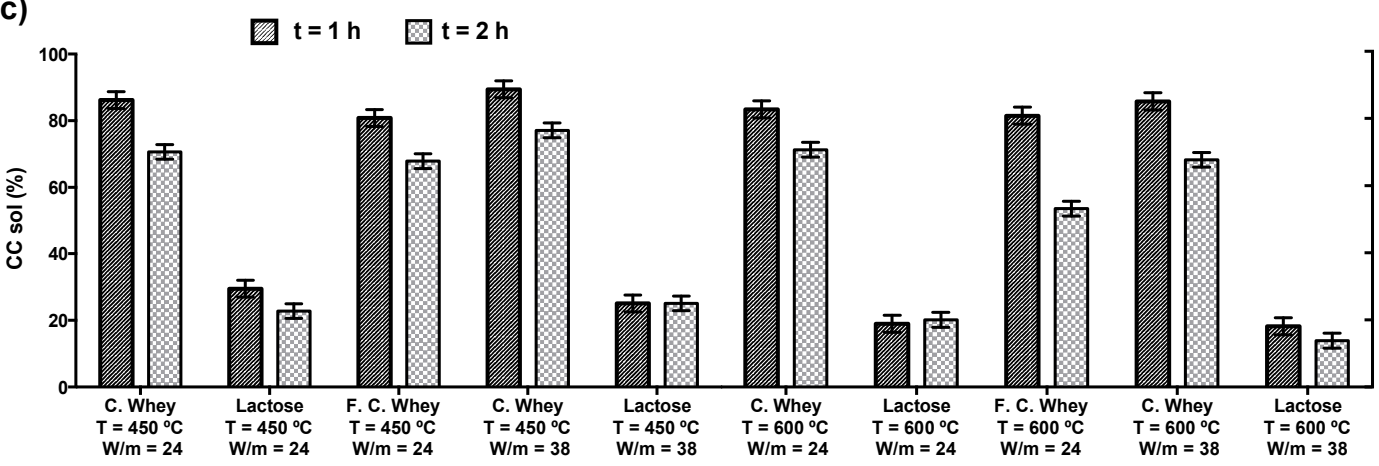

Fig. 1. Carbon conversion to gas (a), liquid (b) and solid (c) obtained in the catalytic steam reforming of cheese whey, filtered cheese whey and lactose. Bars are LSD intervals with $95 \%$ confidence. 
a)

$\mathrm{t}=1 \mathrm{~h} \quad \mathrm{t}=\mathbf{2 h}$

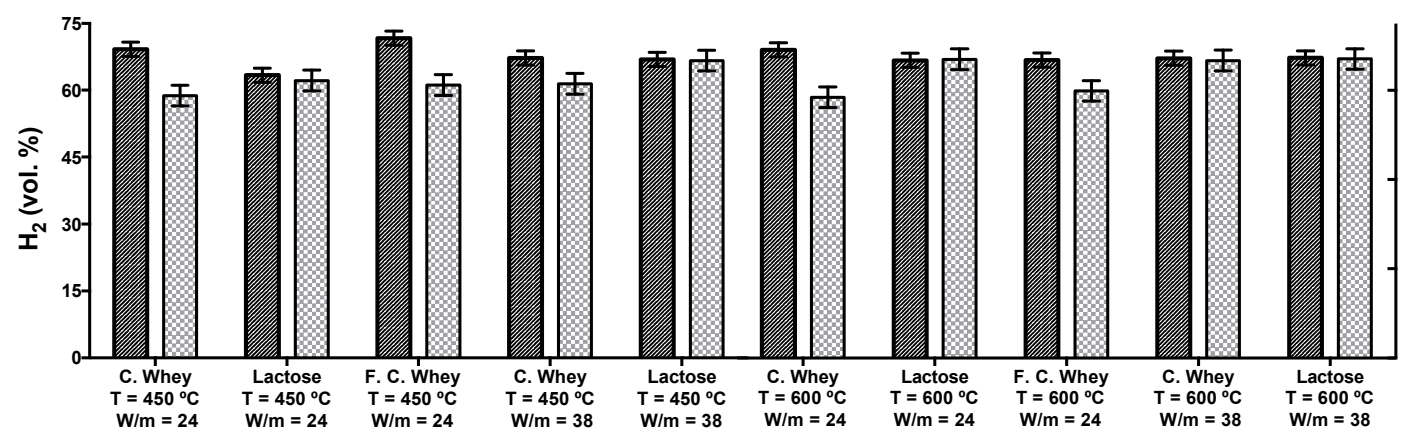

b)

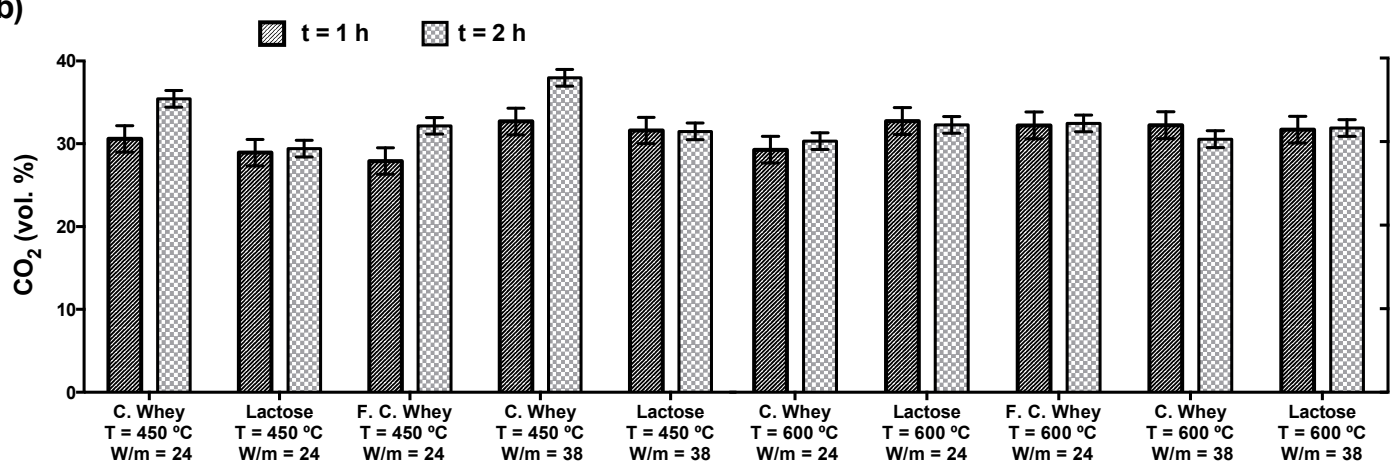

c)
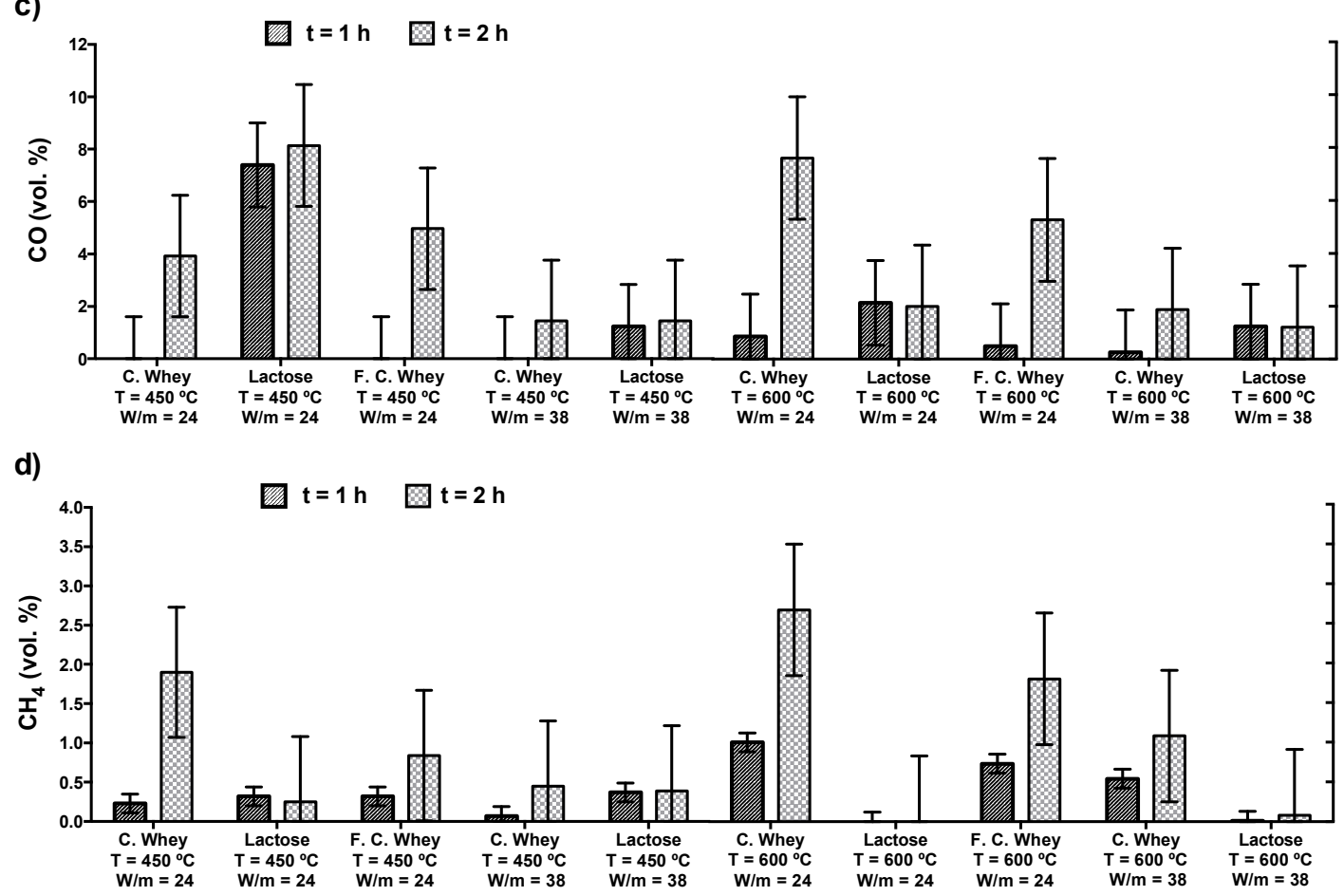

Fig. 2. Relative amounts of $\mathrm{H}_{2}$ (a), $\mathrm{CO}_{2}$ (b) $\mathrm{CO}$ (c) and $\mathrm{CH}_{4}$ (d) obtained in the catalytic steam reforming of cheese whey, filtered cheese whey and lactose. Bars are LSD intervals with $95 \%$ confidence. 

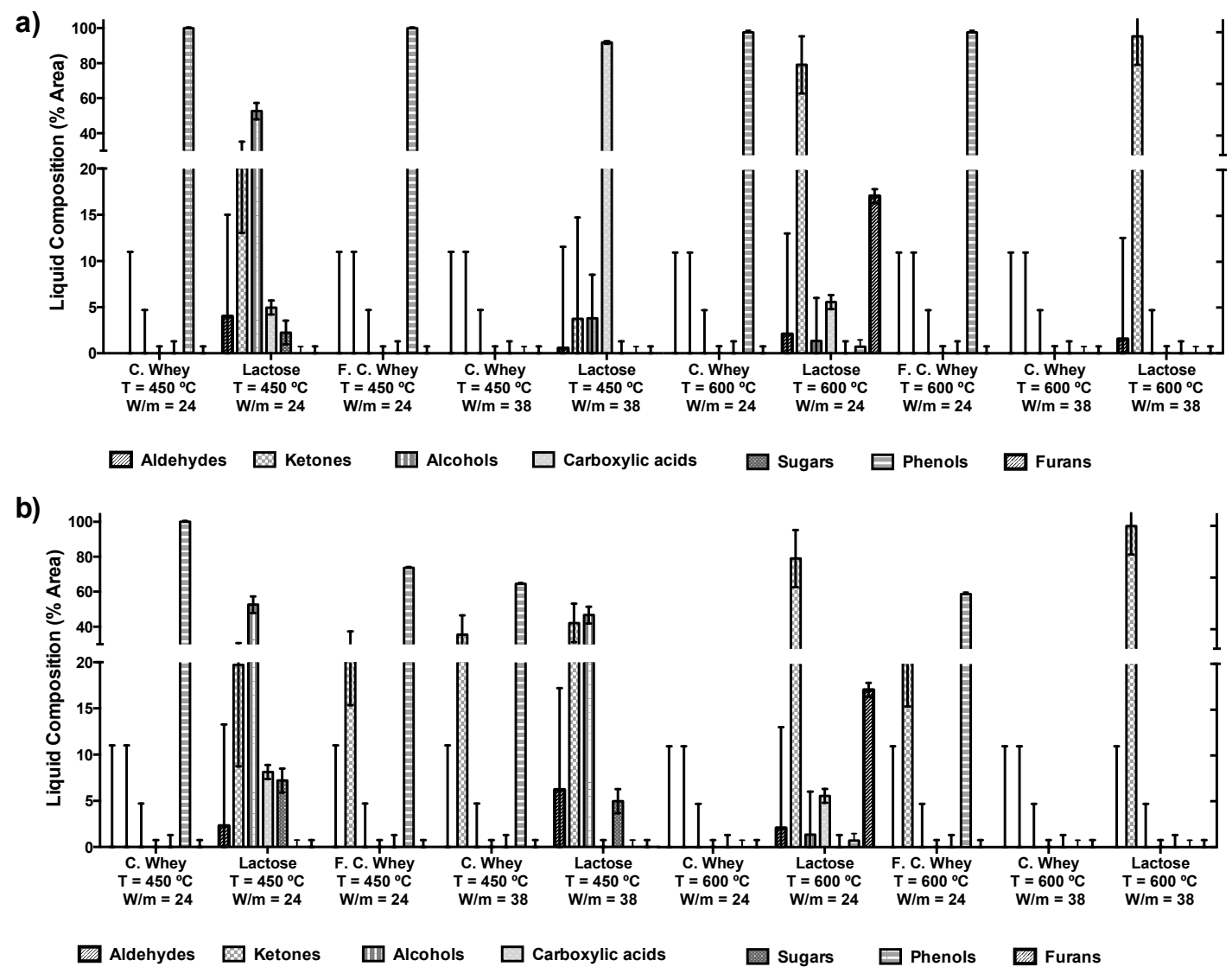

Fig. 3. Composition of the liquid phase obtained during the first (a) and second (b) hour for the catalytic steam reforming of cheese whey, filtered cheese whey and lactose. Bars are LSD intervals with $95 \%$ confidence. 
a)

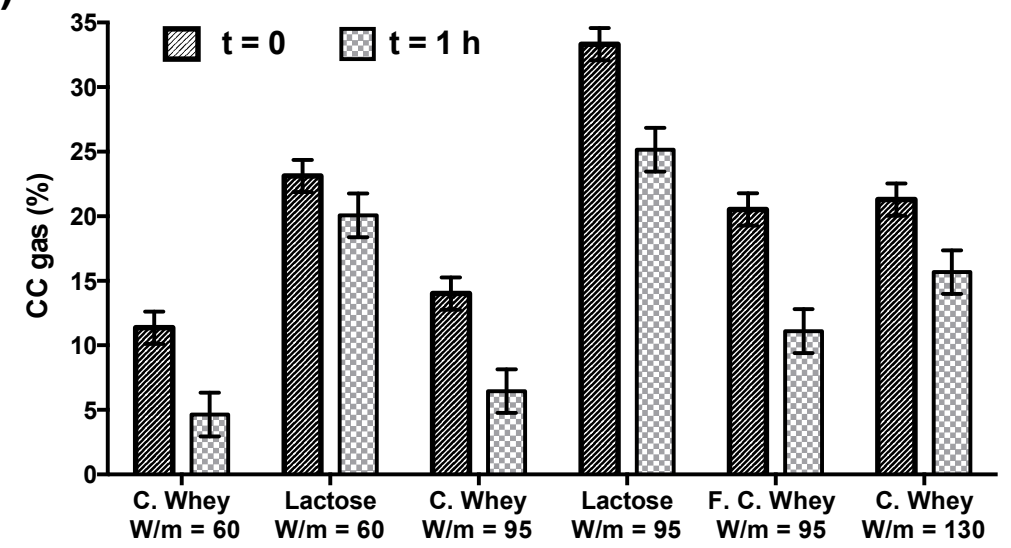

b)

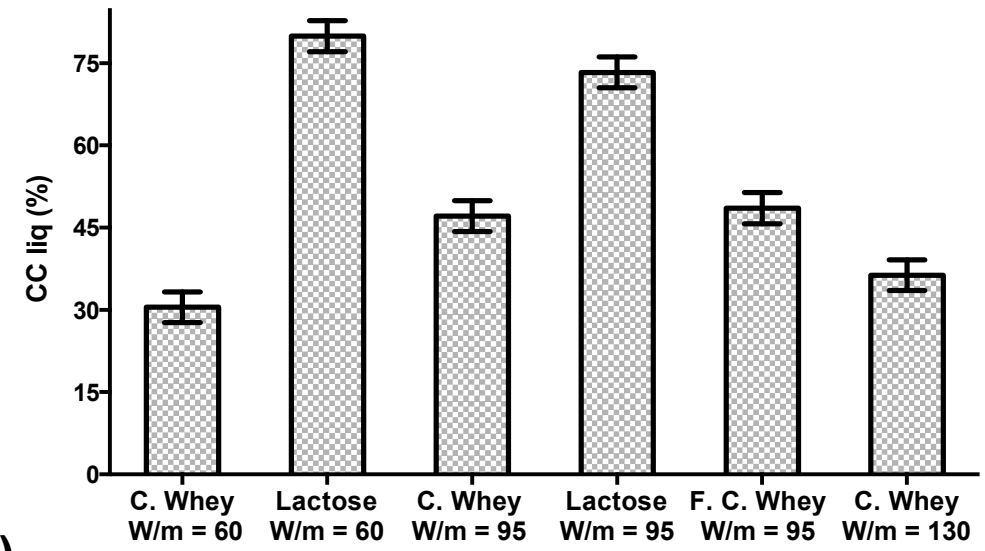

c)

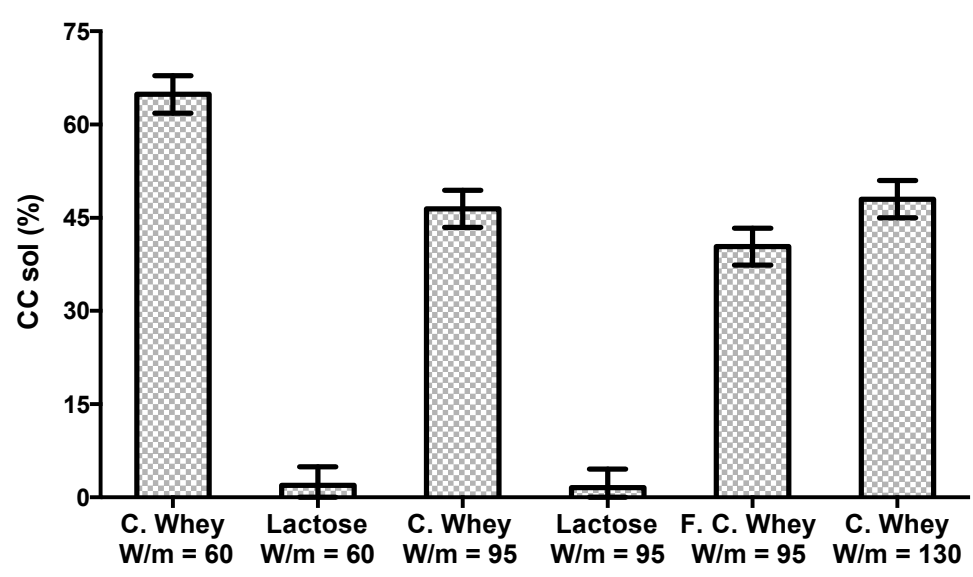

Fig. 4. Carbon conversion to gas (a), liquid (b) and solid (c) obtained in the catalytic aqueous phase reforming of cheese whey, filtered cheese whey and lactose. Bars are LSD intervals with $95 \%$ confidence. 

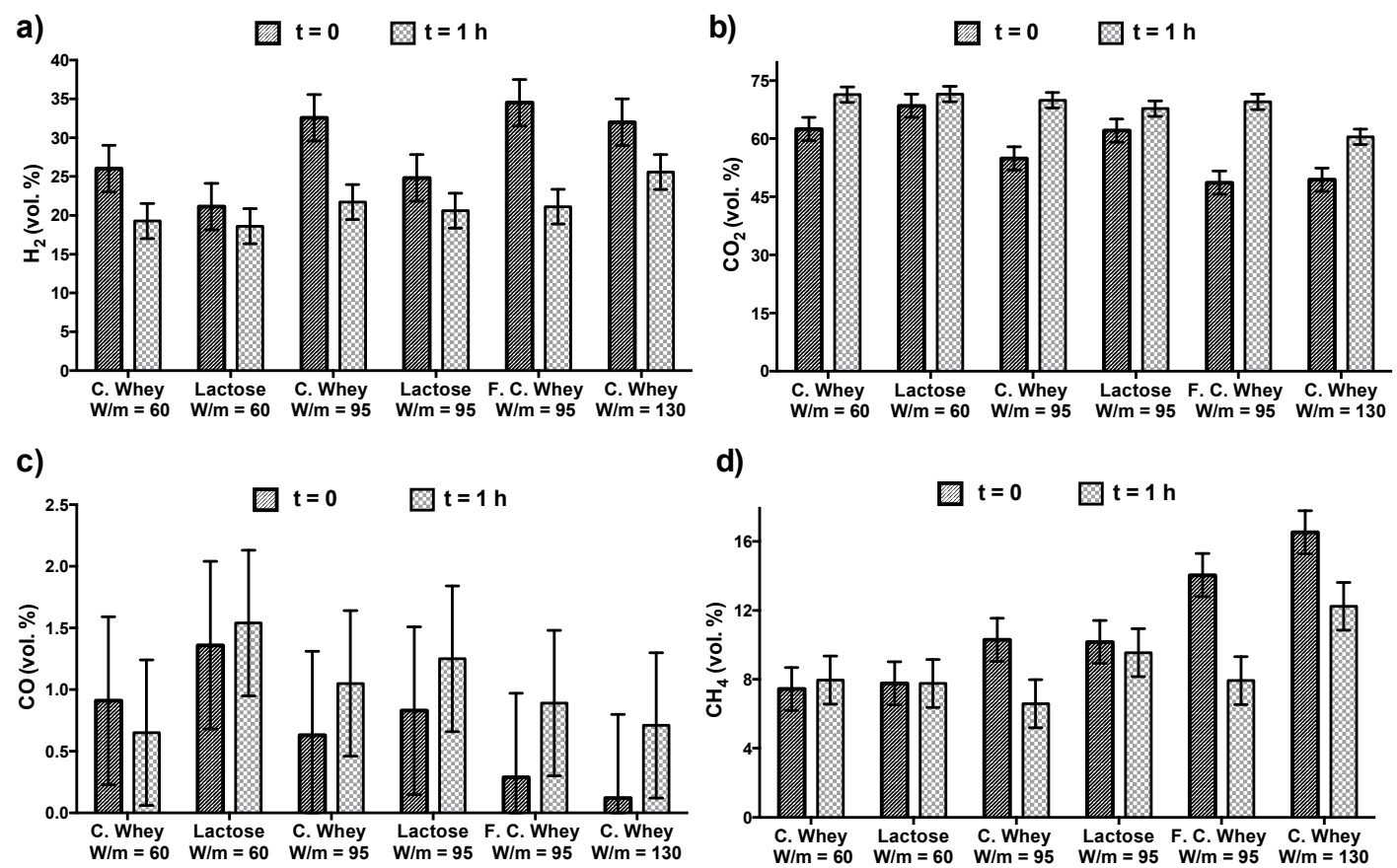

Fig. 5. Relative amounts of $\mathrm{H}_{2}$ (a), $\mathrm{CO}_{2}$ (b) $\mathrm{CO}$ (c) and $\mathrm{CH}_{4}$ (d) obtained in the catalytic aqueous phase reforming of cheese whey, filtered cheese whey and lactose. Bars are LSD intervals with $95 \%$ confidence.

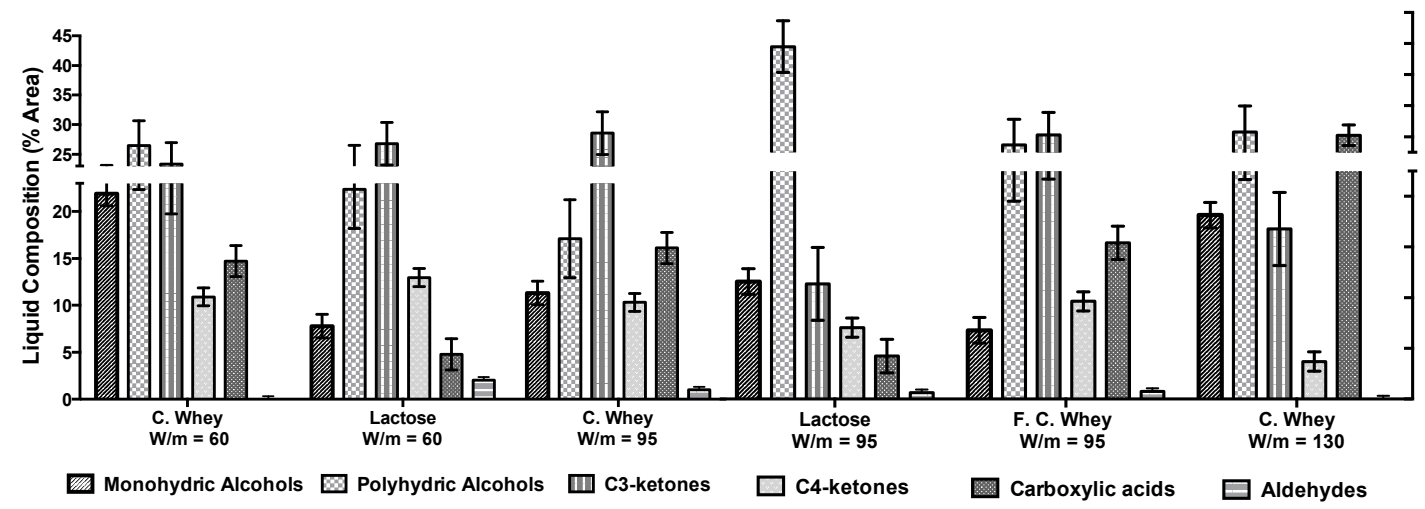

Fig. 6. Composition of the liquid phase obtained in one hour in the catalytic aqueous phase reforming of cheese whey, filtered cheese whey and lactose. Bars are LSD intervals with $95 \%$ confidence. 
a)

\section{Steam reforming}

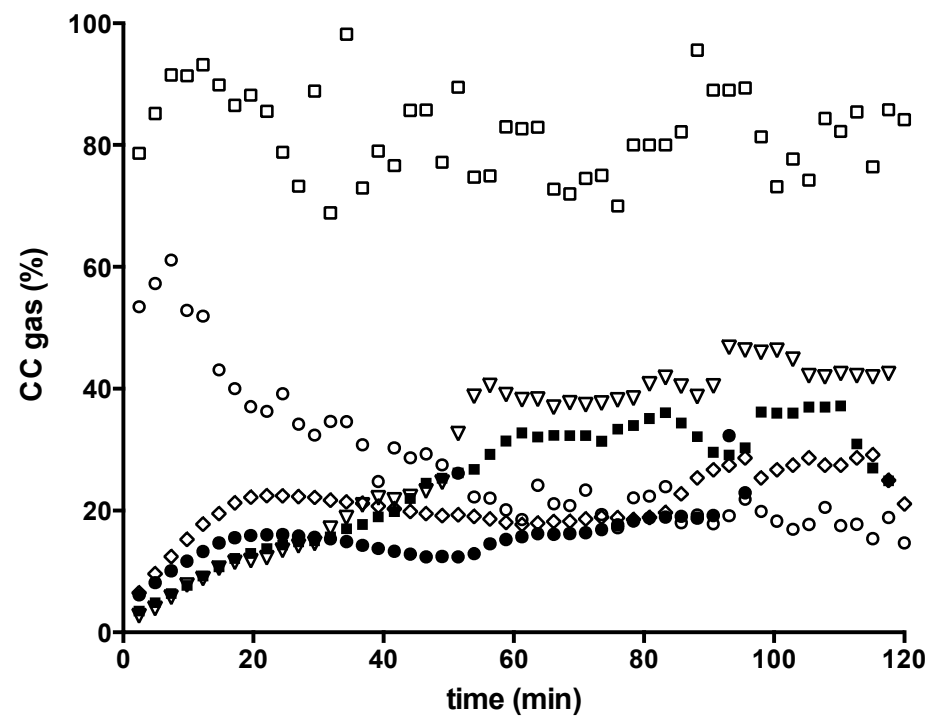

- $\mathrm{CW}-450^{\circ} \mathrm{C}-\mathrm{W} / \mathrm{m} 24$ - $\mathrm{CW}-600^{\circ} \mathrm{C}-\mathrm{W} / \mathrm{m} 24$

$\diamond \mathrm{FCW}-450^{\circ} \mathrm{C}-\mathrm{W} / \mathrm{m} 24 \quad \nabla$ FCW- $600^{\circ} \mathrm{C}-\mathrm{W} / \mathrm{m} 24$

- Lactose $450^{\circ} \mathrm{C}-\mathrm{W} / \mathrm{m} 24$ 口 Lactose $600^{\circ} \mathrm{C}$ W/m 24

b) Aqueous phase reforming

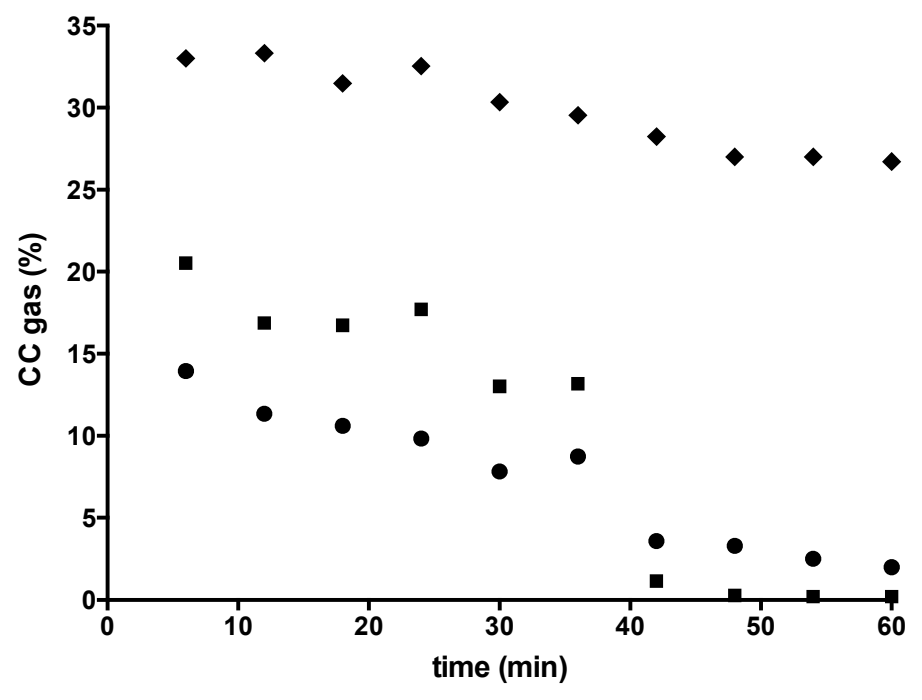

- $\mathrm{CW}-\mathrm{W} / \mathrm{m} 95$ - FCW-W/m 95 Lactose-W/m 95

Fig. 7. Evolution over time of the $\mathrm{CC}$ gas for some a) steam reforming and b) aqueous phase reforming experiments. 
a)

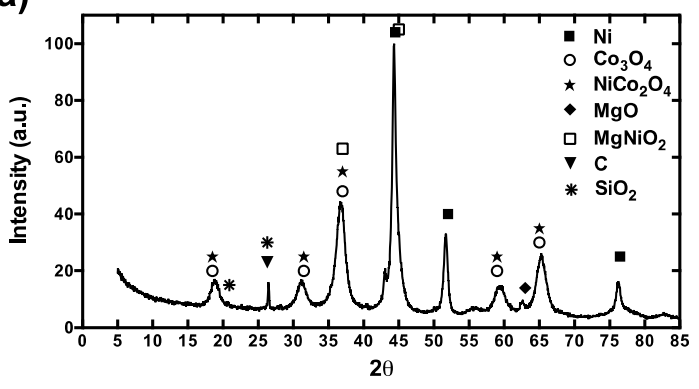

b)

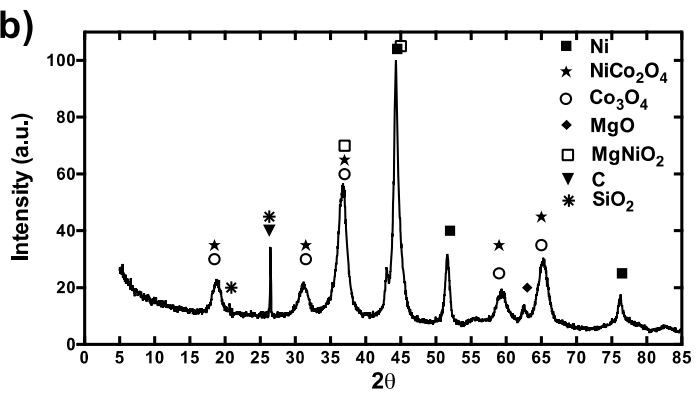

c)

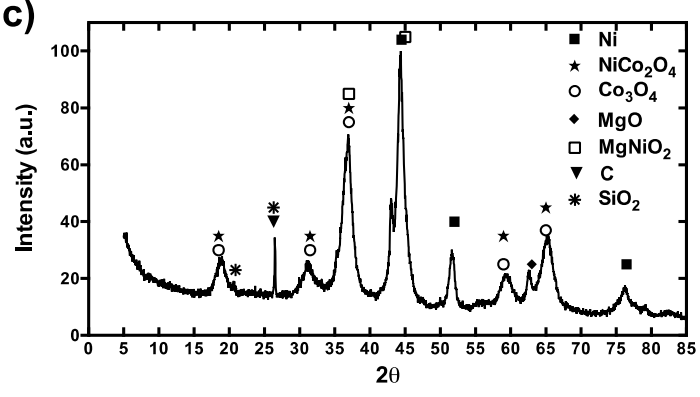

d)

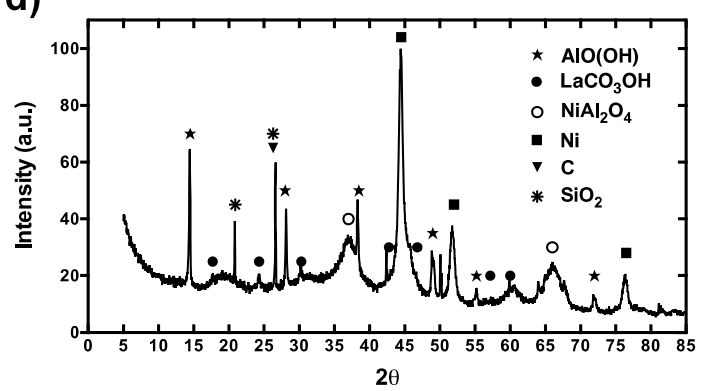

e)
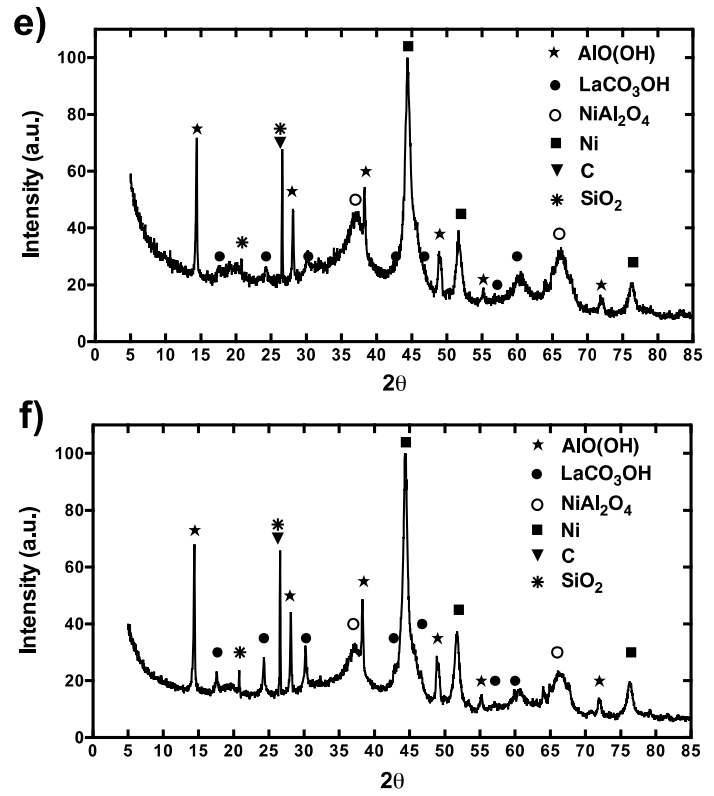

Fig. 8. XRD for some spent catalysts. a) SR-CW-600 ${ }^{\circ} \mathrm{C}-\mathrm{W} / \mathrm{m} 24$, b) SR-FCW-600 ${ }^{\circ} \mathrm{C}-$ $\mathrm{W} / \mathrm{m} 24$, c) SR-Lactose- $600{ }^{\circ} \mathrm{C}-\mathrm{W} / \mathrm{m}$ 24, d) APR-CW-W/m 95, e) APR-FCW-W/m 95, f) APR-Lactose-W/m 95. 